\title{
Review
}

\section{Zingiber officinale var. rubrum: Red Ginger's Medicinal Uses}

\author{
Shiming Zhang ${ }^{1}\left(\mathbb{D}\right.$, Xuefang Kou ${ }^{2}$, Hui Zhao ${ }^{3}$, Kit-Kay Mak ${ }^{1,4,5}$, Madhu Katyayani Balijepalli ${ }^{6}$ \\ and Mallikarjuna Rao Pichika ${ }^{4,5, *}$
}

1 School of Postgraduate Studies, International Medical University, Kuala Lumpur 57000, Malaysia; zhang.shiming@student.imu.edu.my (S.Z.); kitkaymak@imu.edu.my (K.-K.M.)

2 Experimental Centre, Shandong University of Traditional Chinese Medicine, Jinan 250355, China; kouxuefang@126.com

3 School of Pharmacy, Shandong University of Traditional Chinese Medicine, Jinan 250355, China; zhaohui20222022@163.com

4 Pharmaceutical Chemistry Department, School of Pharmacy, International Medical University, Kuala Lumpur 57000, Malaysia

5 Centre for Bioactive Molecules and Drug Delivery, Institute for Research, Development \& Innovation (IRDI), International Medical University, Kuala Lumpur 57000, Malaysia

6 Department of Pharmacology, Faculty of Medicine and Health Sciences, MAHSA University, Selangor 42610, Malaysia; madhu@mahsa.edu.my

* Correspondence: mallikarjunarao@imu.edu.my

Citation: Zhang, S.; Kou, X.; Zhao, H.; Mak, K.-K.; Balijepalli, M.K.;

Pichika, M.R. Zingiber officinale var. rubrum: Red Ginger's Medicinal Uses. Molecules 2022, 27, 775. https:// doi.org/10.3390/molecules27030775

Academic Editor: Claudio Ferrante

Received: 27 December 2021

Accepted: 18 January 2022

Published: 25 January 2022

Publisher's Note: MDPI stays neutral with regard to jurisdictional claims in published maps and institutional affiliations.

Copyright: () 2022 by the authors Licensee MDPI, Basel, Switzerland. This article is an open access article distributed under the terms and conditions of the Creative Commons Attribution (CC BY) license (https:// creativecommons.org/licenses/by/ $4.0 /)$.

\begin{abstract}
Zingiber officinale var. rubrum (red ginger) is widely used in traditional medicine in Asia. Unlike other gingers, it is not used as a spice in cuisines. To date, a total of 169 chemical constituents have been reported from red ginger. The constituents include vanilloids, monoterpenes, sesquiterpenes, diterpenes, flavonoids, amino acids, etc. Red ginger has many therapeutic roles in various diseases, including inflammatory diseases, vomiting, rubella, atherosclerosis, tuberculosis, growth disorders, and cancer. Scientific evidence suggests that red ginger exhibits immunomodulatory, antihypertensive, antihyperlipidemic, antihyperuricemic, antimicrobial, and cytotoxic activities. These biological activities are the underlying causes of red ginger's therapeutic benefits. In addition, there have been few reports on adverse side effects of red ginger. This review aims to provide insights in terms the bioactive constituents and their biosynthesis, biological activities, molecular mechanisms, pharmacokinetics, and qualitative and quantitative analysis of red ginger.
\end{abstract}

Keywords: Zingiber officinale var. rubrum; red ginger; bioactive constituents; biosynthesis; biological activities; molecular mechanisms; pharmacokinetics; analysis

\section{Introduction}

Ginger, the rhizome of Zingiber officinale, consisting of seven species, is mainly distributed in Asia (Figure 1) [1]. Since antiquity, ginger has been used for a wide array of unrelated ailments such as arthritis, rheumatism, sprains, muscular aches, pains, sore throats, cramps, constipation, indigestion, vomiting, hypertension, dementia, fever, infectious diseases, and helminthiasis. The main biological activities of ginger are immunomodulatory, antitumorigenic, anti-inflammatory, antiapoptotic, antihyperglycemic, antilipidemic, and antiemetic. Ginger is a potent antioxidant, and either mitigates or prevents the generation of free radicals. It is considered a safe herbal medicine with only a few side effects.

There is a taxonomic challenge when identifying the correct species as many synonyms are reported for ginger. There are eight plant names for the species Zingiber officinale in the plant database (www.theplantlist.org; accessed on 20 November 2021), of which two are accepted names and six are synonyms. Based on the size and color of the rhizome, common ginger can be categorized into three varieties: giant ginger or white ginger (Zingiber officinale Rosc. var. officinale), small white ginger or emprit ginger Rhizome (Zingiber. officinale var. amarum), and red ginger (Zingiber officinale var. rubrum) [1-3]. Red ginger belongs to the 
Spermatophyta division, Angiospermae subdivision, Monocotyledoneae class, Zingiberales order, and Zingiberaceae family. Its scientific botanical name is Zingiber officinale Roscoe var. rubrum. Its synonyms are Zingiber officinale Roscoe var Sunti Val., Zingiber amomum L., Zingiber cholmondeleyi (F.M. Bailey) K. Schum., Zingiber missionis Wall., Zingiber officinale var. macrorhizonum Makino, Zingiber officinale var. rubens Makino, and Zingiber sichuanense. It is red, with a yellow to pink cross section on the outside of the rhizomes, while the base of the leaf shoot is red. It is an annual plant that grows up to $50-100 \mathrm{~cm}$ high. The rhizomes are thick and reddish-brown. It is morphologically similar to common ginger. It is smaller and more pungent than common ginger. The leaves are narrow and lancet-shaped, 5-25 cm in length and 8-20 $\mathrm{mm}$ in width. The plant has an ovoid-shaped composite that emerges from the rhizomes, with a stem length of 10-25 cm and small leaves at the base of the flower. The corollas are funnel-shaped, $2-2.5 \mathrm{~cm}$ long, and dark purple with creamy yellow spots. The petals are small, tubular, and tridentate. Unlike common ginger, its petiole is reddish, and the lip is scarlet red [4]. Red ginger is mainly cultivated in China, Indonesia, and Malaysia. Photographs of red ginger, common ginger, and the whole plant of red ginger are shown in Figure 1 [1].
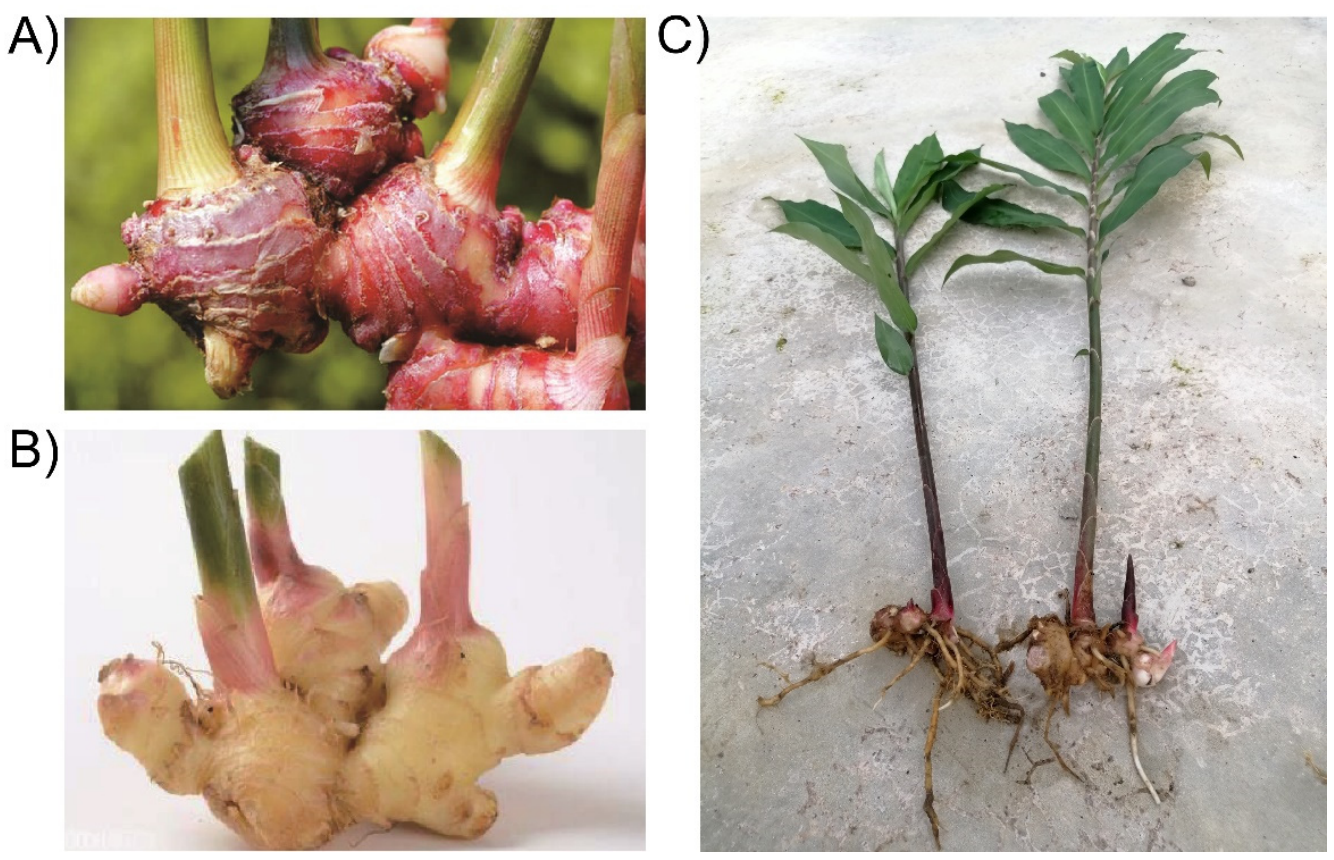

Figure 1. Photographs of (A) Red ginger (Zingiber officinale var. rubrum), (B) common ginger, and (C) whole plant of Zingiber officinale var. rubrum.

The Pubmed, Scopus, and Web of Science databases were used to collect the information on red ginger. The keywords used were "Zingiber officinale var. rubrum", "Halia Bara", and "red ginger". Only articles published in English are included in this review. A few additional references from the web that were deemed useful for the completion of this review article were included.

To the best of our knowledge, this review article is the first on Zingiber officinale var. rubrum. This review aims to provide an exhaustive summary of the (1) traditional uses, (2) chemical constituents and their biosynthesis, (3) bioactivities and molecular mechanisms, (4) analysis and quality control, and (5) medicinal products. Research gaps in the literature are identified and we have suggested future research opportunities. Perspectives on further improving the medicinal value of red ginger are provided. 


\section{Chemical Constituents of Red Ginger and Its Biosynthesis}

The chemical composition of red ginger is complex, containing about 169 chemical constituents [4-13]. The chemical constituents include monoterpenes, sesquiterpenes, diterpenes, vanilloids, flavonoids, etc. The biological activities of red ginger might be due to the synergistic or additive effects of these compounds. In addition, red ginger contains amino acids, vitamins, and trace elements (iron, copper, manganese, zinc, chromium, nickel, strontium, etc.) [14]. Ghasemzadeh et al. [15] reported that the total number of phenolic and flavonoids in red ginger is higher than in common ginger. Sivasothy et al. [4], using GC-MS, characterized the chemical composition of red ginger oil. It contains three predominant monoterpenes (camphene $(14.5 \%)$, geranial $(14.3 \%)$, and geranyl acetate $(13.7 \%))$ and 47 sesquiterpenes. Ten flavonoids were reported in red ginger [16]. It has been reported that extraction with carbon dioxide increases the total flavonoid content in red ginger [17]. The major bioactive compounds in red ginger are vanilloids containing a 3-methoxy-4-hydroxyphenyl (vanillyl) moiety [18]. The concentrations of vanilloids are higher in red ginger $[19,20]$ than in common ginger. Based on the chemistry of the side chain in vanilloids, they are divided into gingerols, shogaols, paradols, zingerones, gingerdiones, gingerdiols, etc. [21]. Kusumawati et al. determined the vanilloid content using UV-Visible spectrophotometry [5]. Red ginger's oleoresin contains $80.06 \%$ gingerols and $8.02 \%$ shogaols [5]. The vanilloids contribute to the spiciness of the red ginger, of which 6-gingerol and 6-shogaol are the most abundant [18]. Gingerols (4-, 6-, 8-, 10-, and 12-gingerol) are predominant in fresh ginger [22], whereas shogaols (6-, 8-, and 10shogaol) are predominant in dry ginger [23]. Ghasemzadeh et al. reported optimum extraction conditions to obtain oleoresin with the highest content of 6-gingerol and 6-shogaol [24]. Extraction of red ginger with methanol at $76.9^{\circ} \mathrm{C}$ for $3.4 \mathrm{~h}$ yields $2.89 \mathrm{mg} / \mathrm{g}$ 6-gingerol and $1.85 \mathrm{mg} / \mathrm{g}$ 6-shogaol. Eleven vanilloids have been reported in red ginger; the structures are characterized using Nuclear Magnetic Resonance (NMR) spectroscopy and Matrix-assisted laser desorption/ionization-time of flight mass spectrometry (MALDI-TOFMS) [25].

The chemical structures of constituents and their respective compound classes are recorded in Table 1.

Table 1. The main chemical constituents of red ginger.

Same Vanilloids


Table 1. Cont.

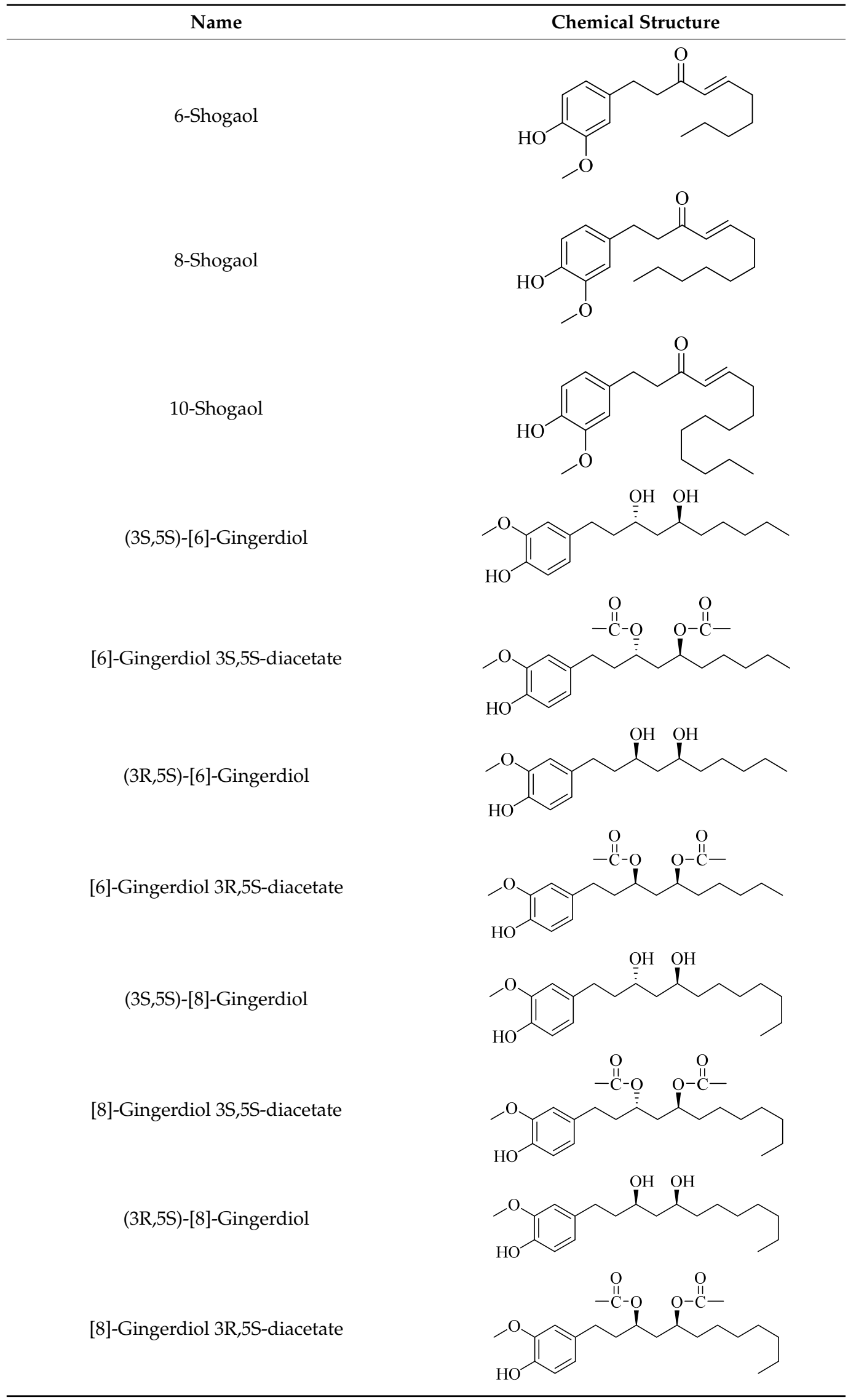


Table 1. Cont.

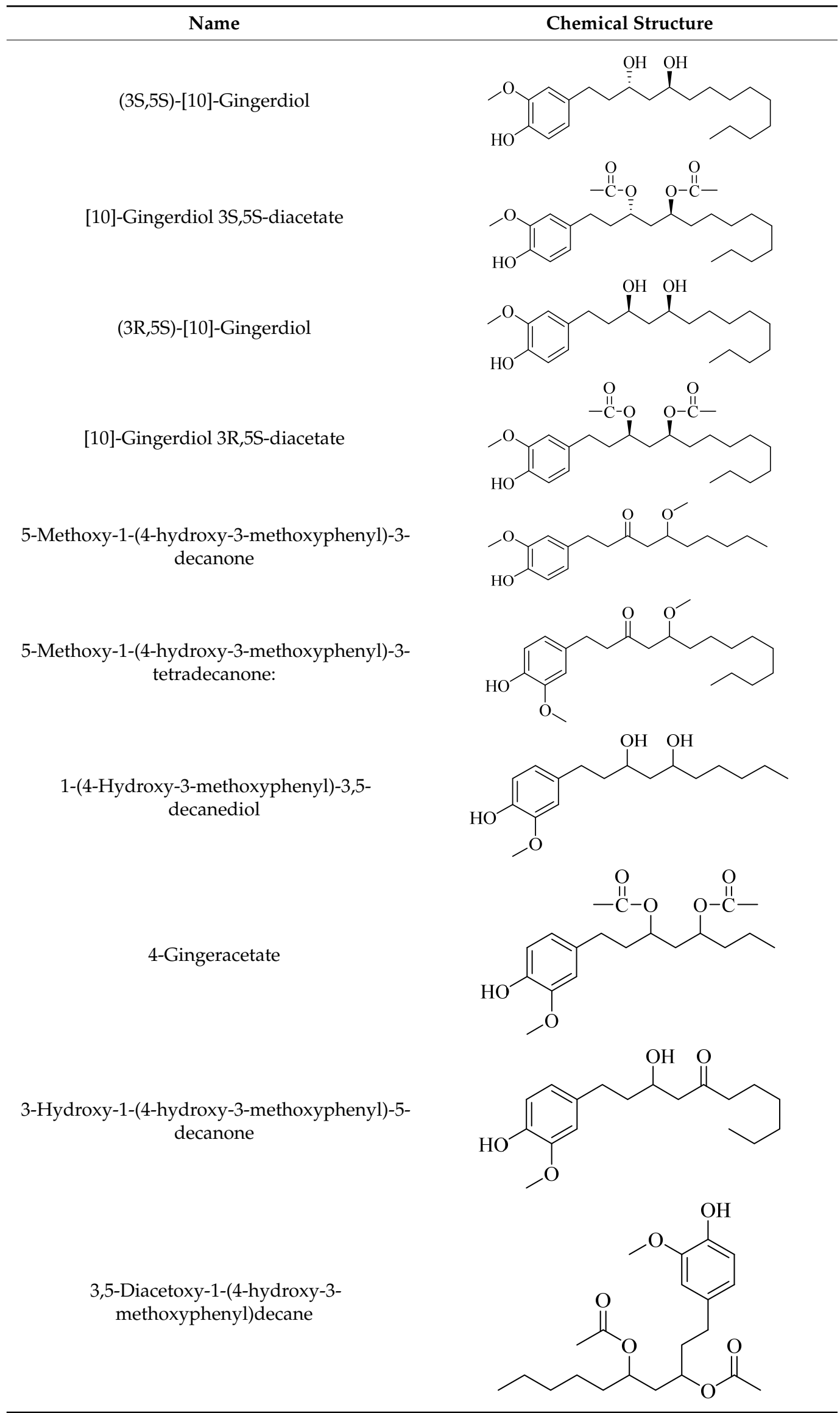


Table 1. Cont.

1-Dehydro-6-gingerdione

Monoterpenes

Tricyclene

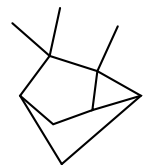

$\alpha$-Pinene

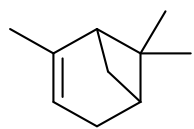

Camphene

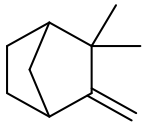

Sabinene

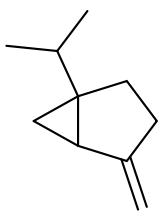

$\beta$-pinene

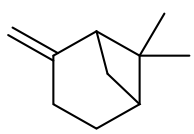

$\alpha$-Phellandrene

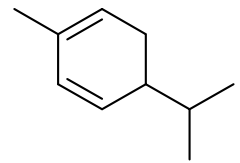

p-Cymene<smiles>Cc1ccc(C(C)C)cc1</smiles>

$\beta$-Phellandrene<smiles>C=C1C=CC(C(C)C)CC1</smiles>

$\gamma$-Terpinene

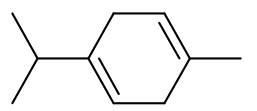

Terpinolene

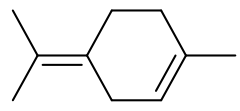

Linalool

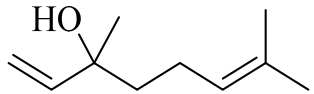


Table 1. Cont.

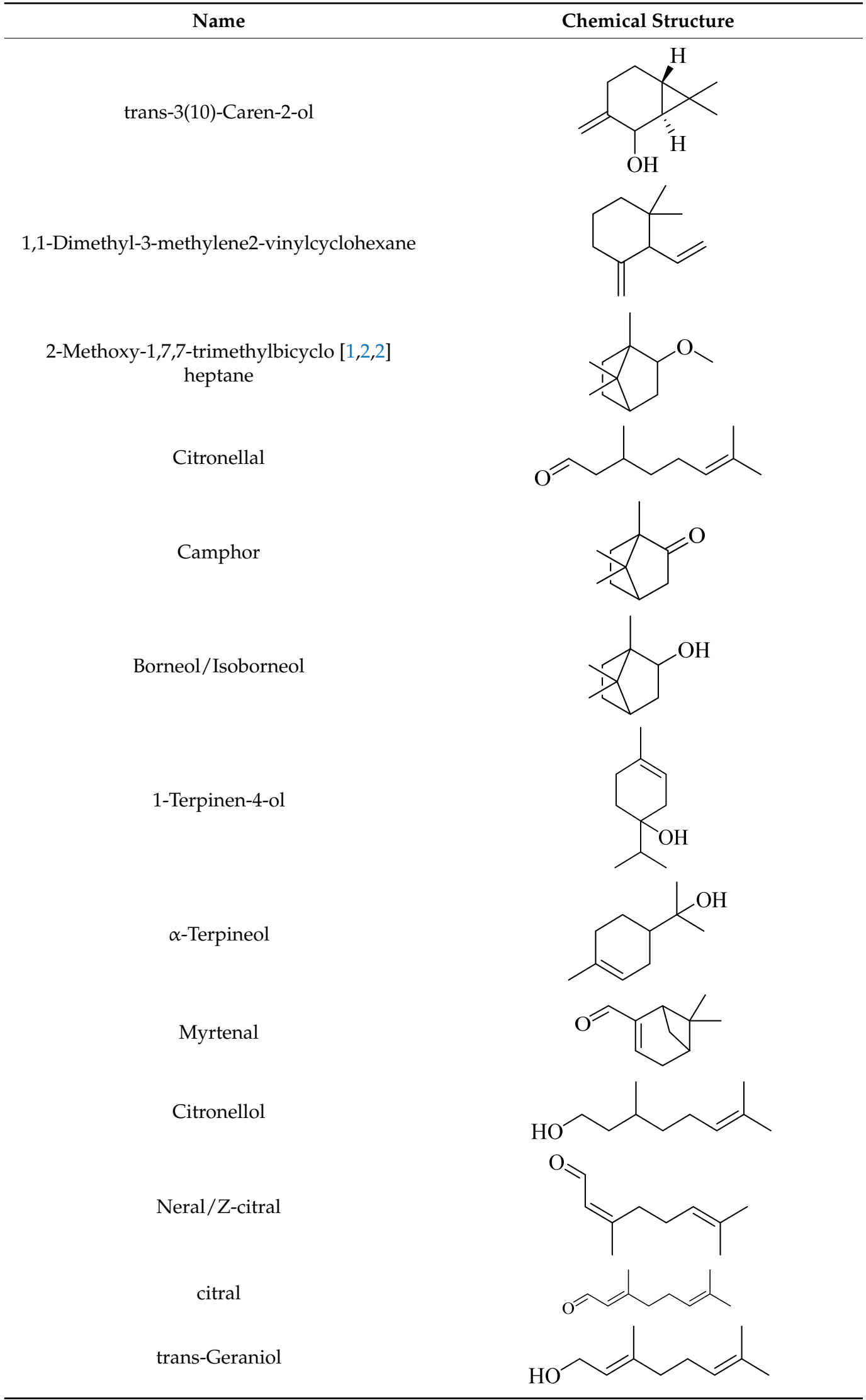


Table 1. Cont.

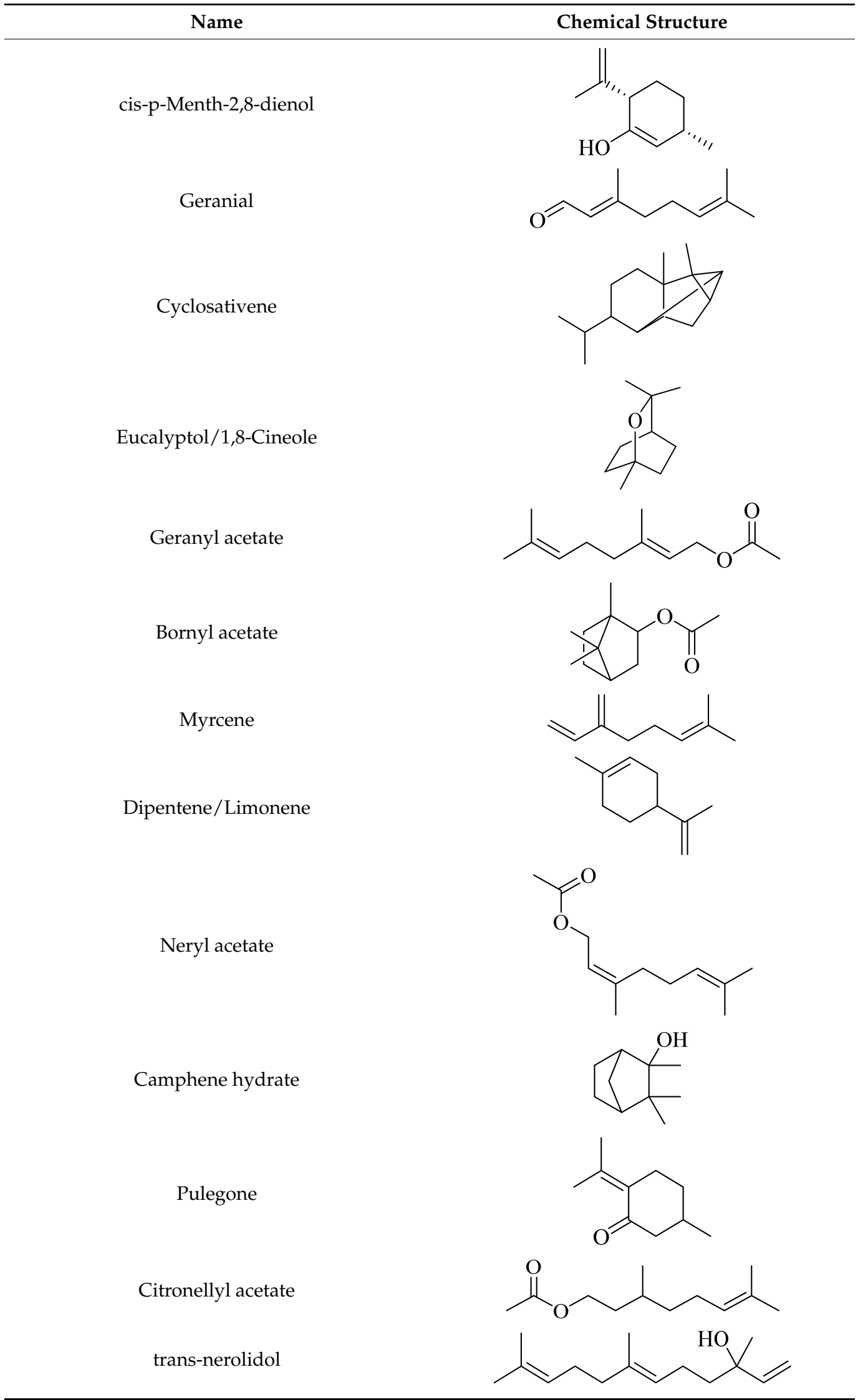


Table 1. Cont.

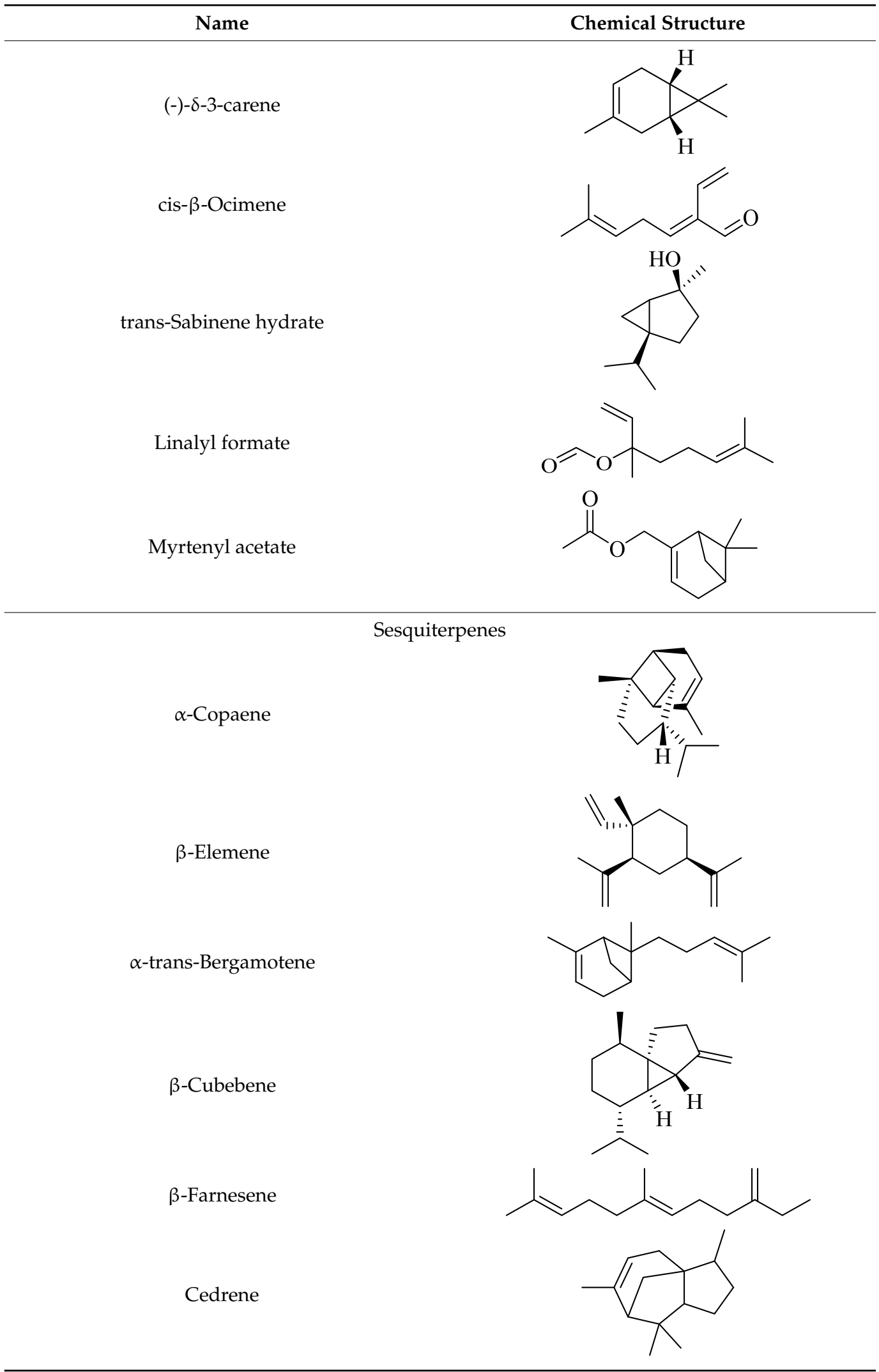


Table 1. Cont.

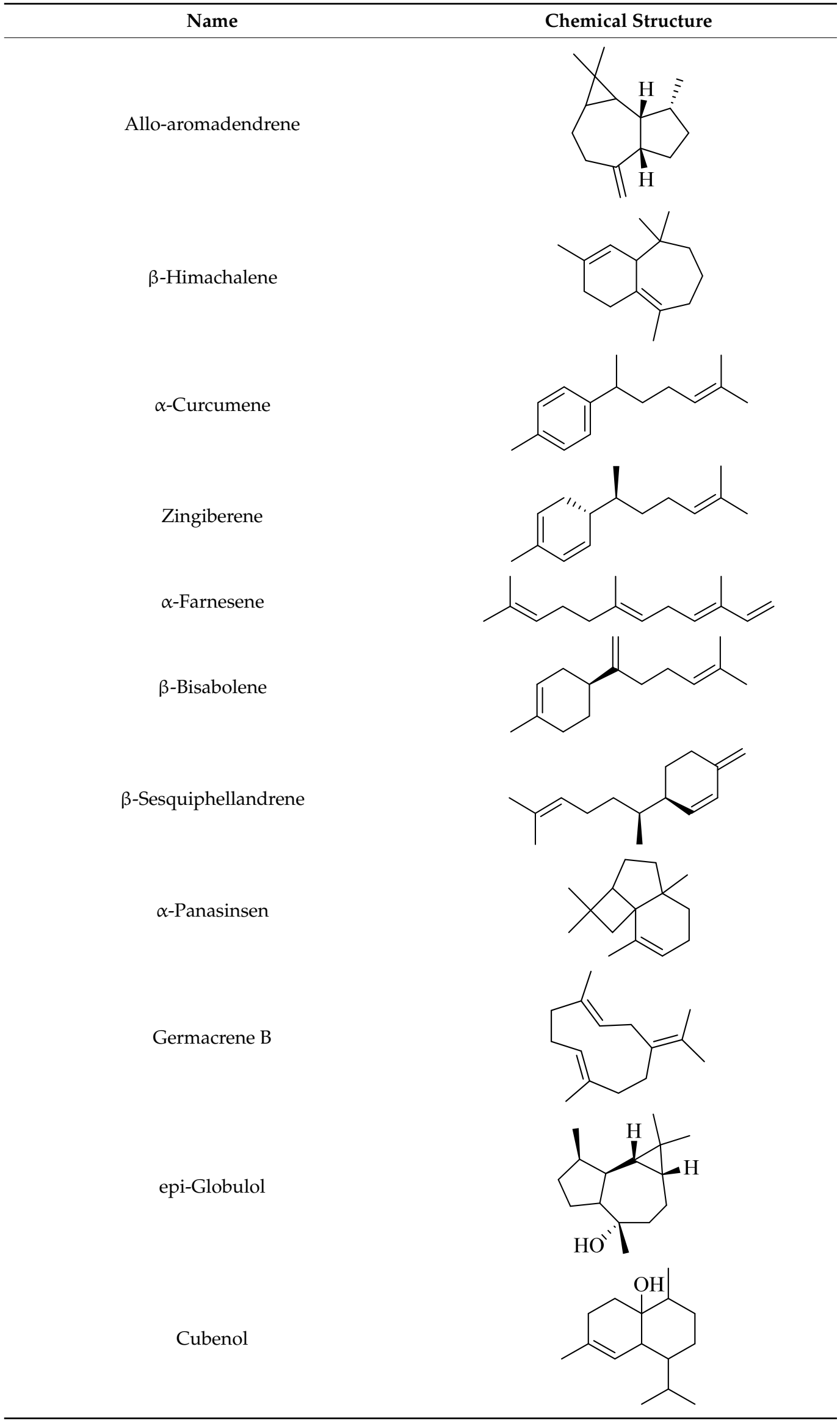


Table 1. Cont.

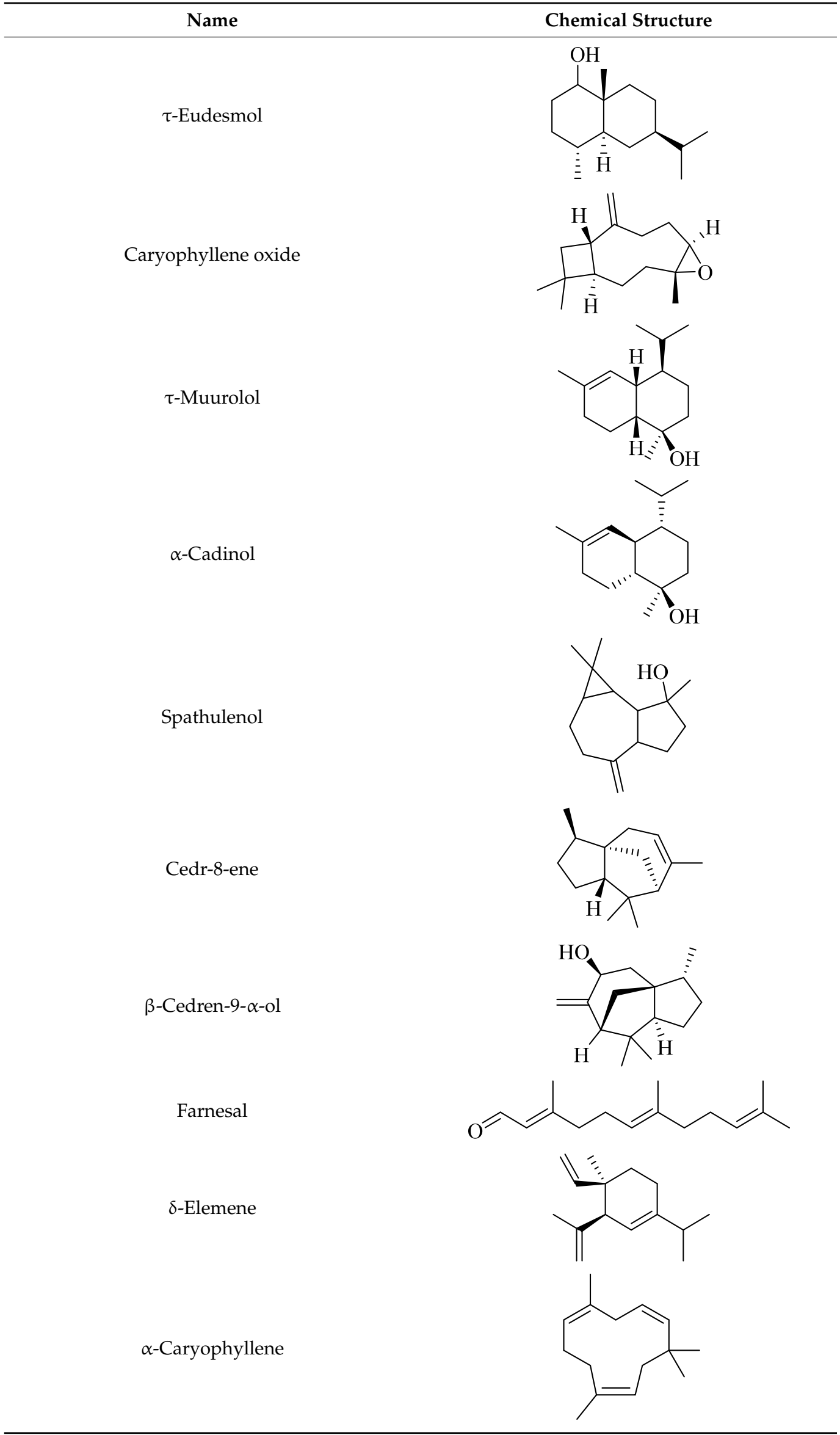


Table 1. Cont.

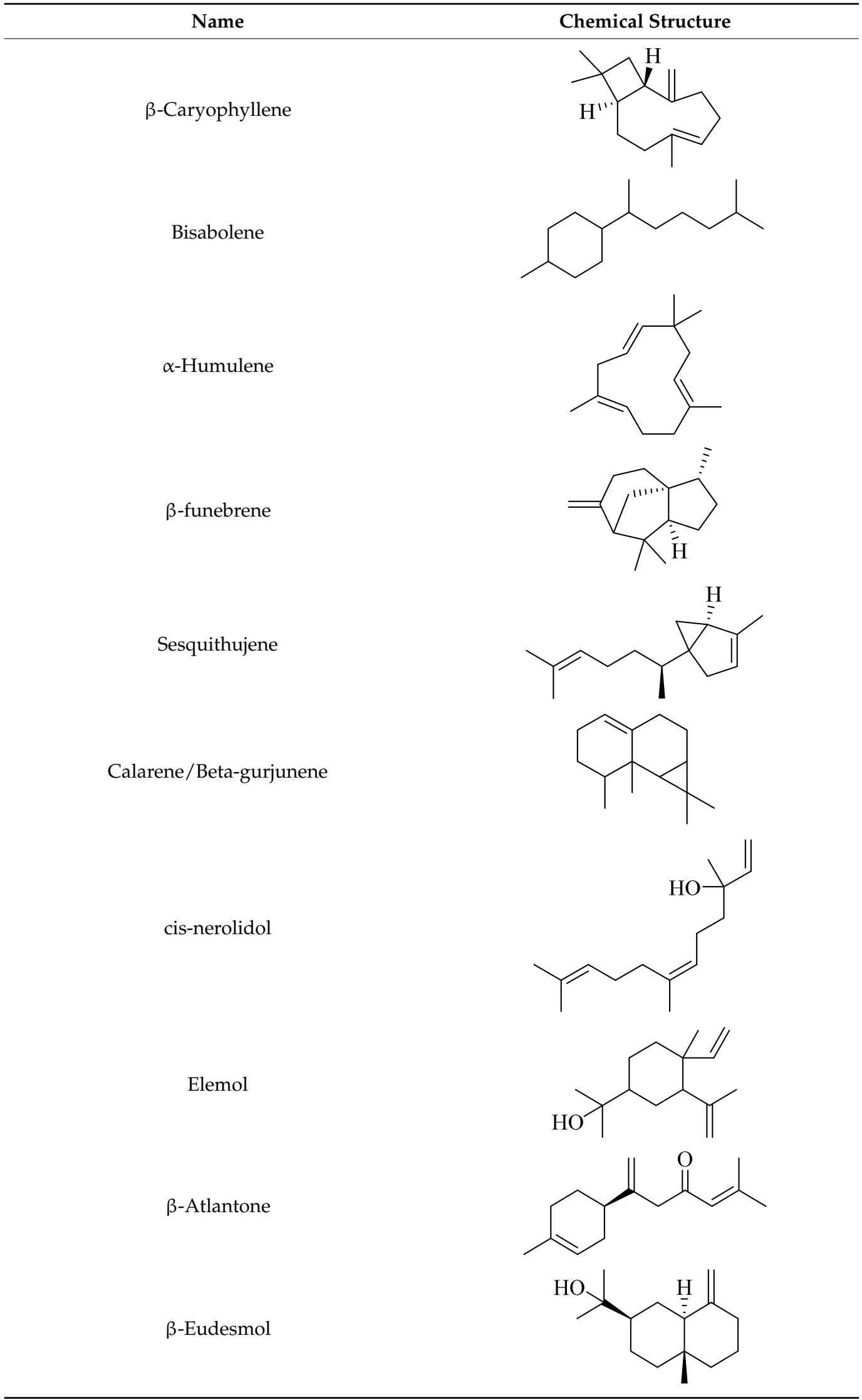


Table 1. Cont.

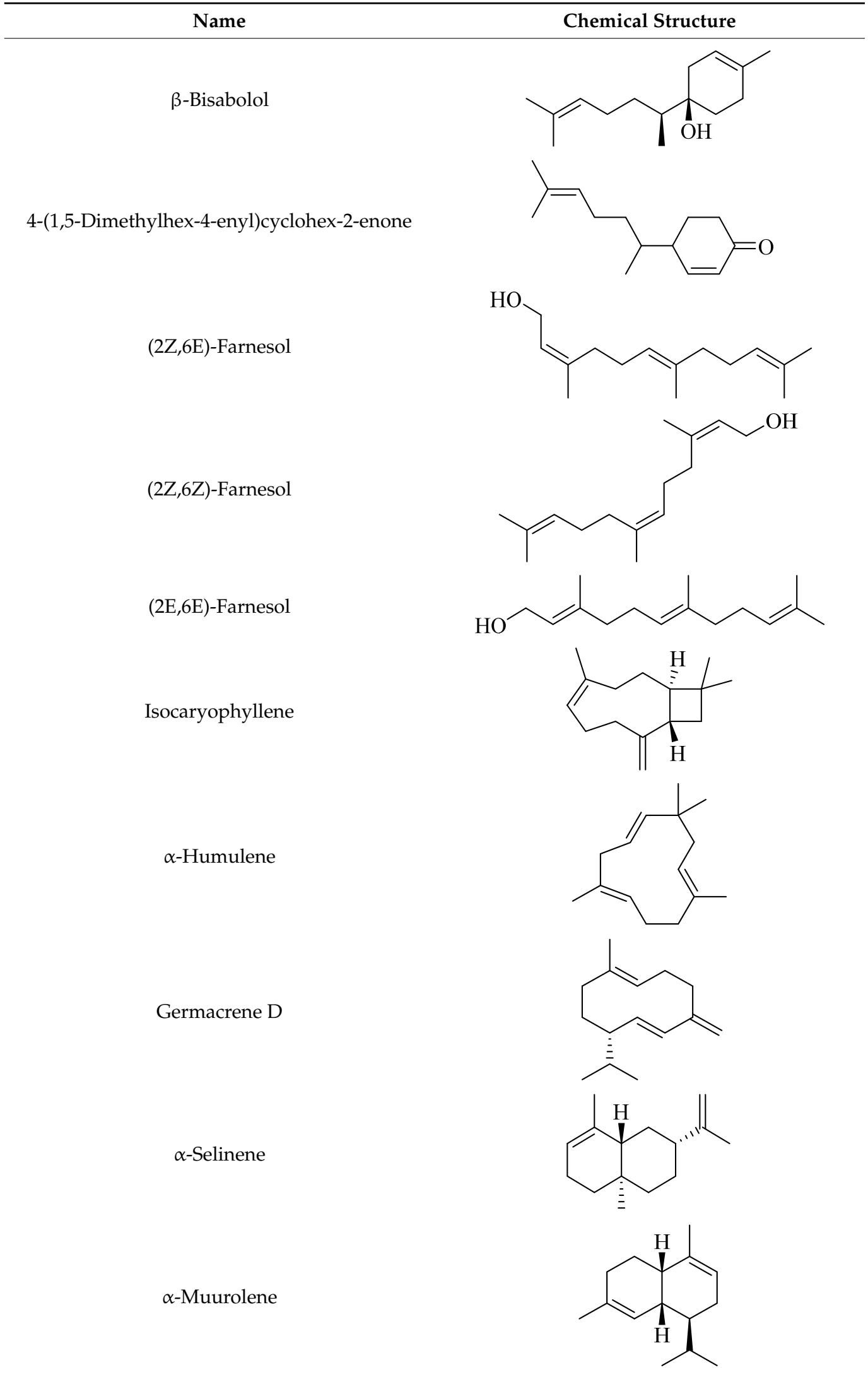


Table 1. Cont.

S-Cadinene

\section{Diterpene}

Phytol

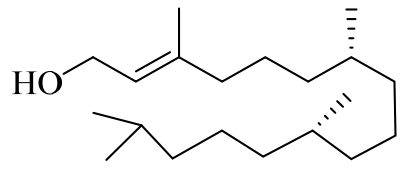

Flavonoids

Rutin<smiles>O=c1c(OC2C[C@@H]3O[C@@H](COC4OC(O)C(O)C3O4)O2)c(-c2ccc(O)c(O)c2)oc2cc(O)cc(O)c12</smiles>

Apigenin<smiles>O=c1cc(-c2ccc(O)cc2)oc2cc(O)cc(O)c12</smiles>

Myricetin<smiles>O=c1c(O)c(-c2cc(O)c(O)c(O)c2)oc2cc(O)cc(O)c12</smiles> 
Table 1. Cont.

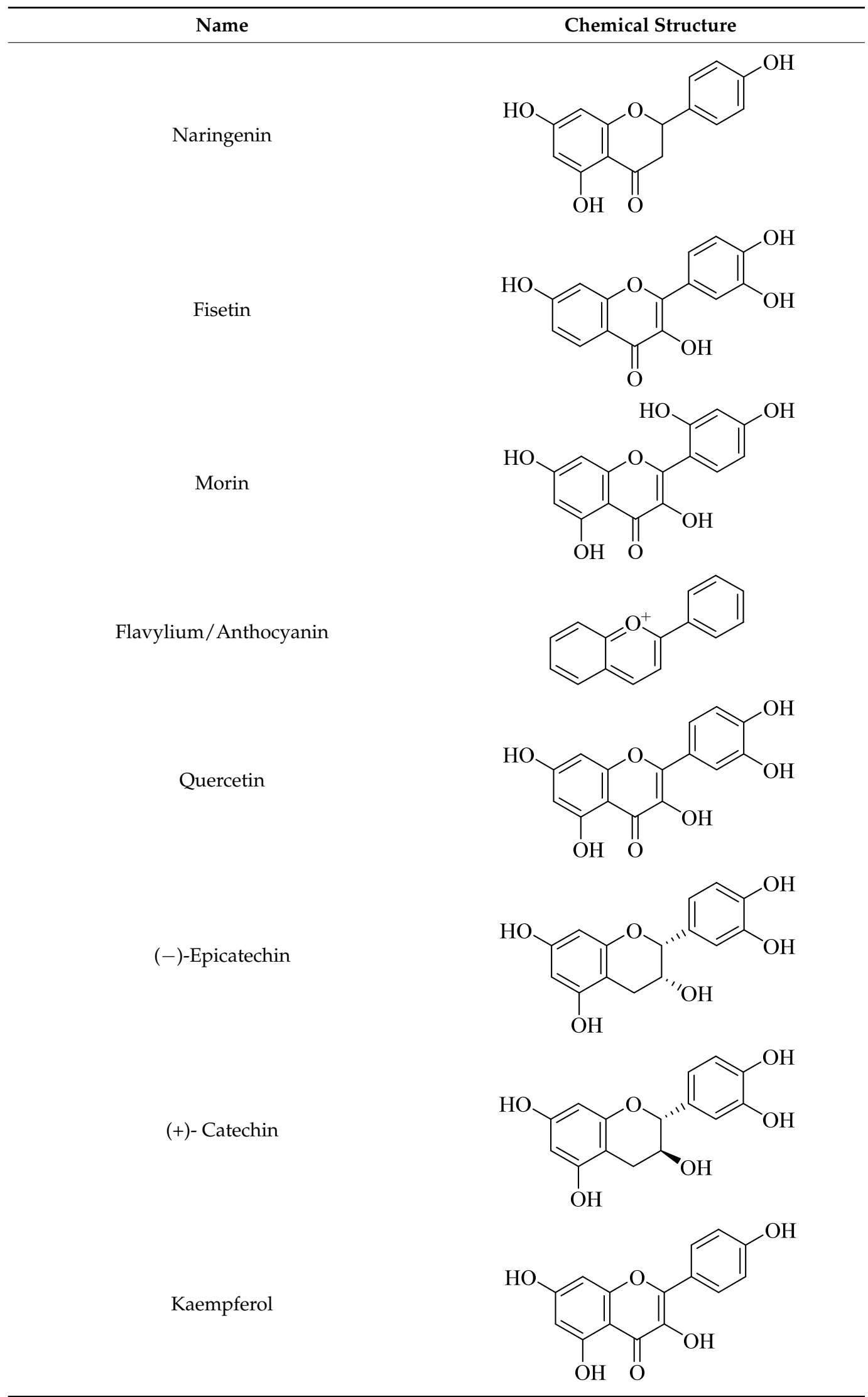


Table 1. Cont.

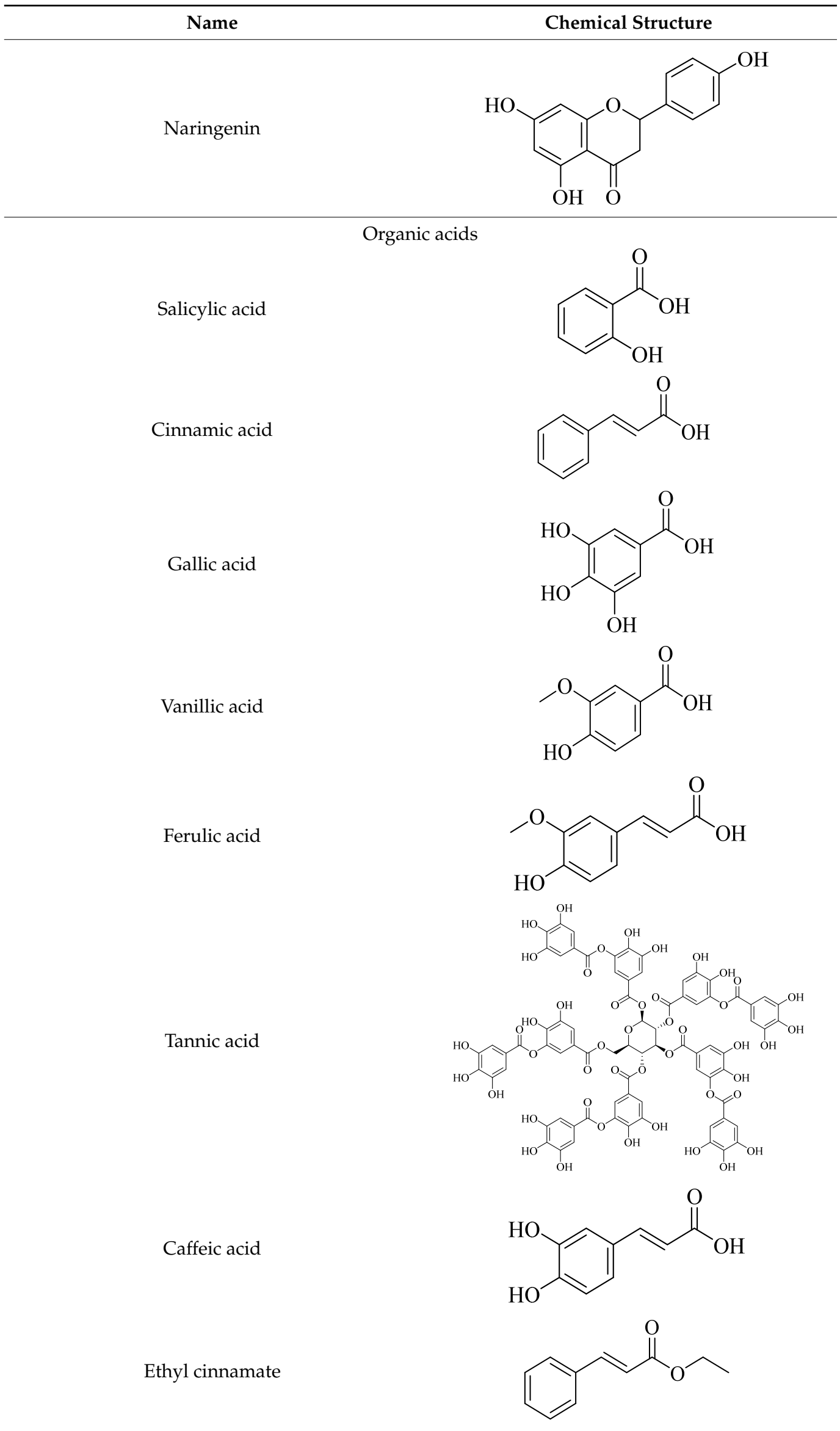


Table 1. Cont.

Name

Ethyl p-methoxycinnamate

2R,4S,5R)-2-(Acetoxymethyl)-6-(2-methoxy-4-

((E)-3-oxodec-4-en-1-yl)phenoxy)tetrahydro2H-pyran-3,4,5-triyl triacetate

(E)-1-(3-Methoxy-4-((3R,4S,6R)-3,4,5trihydroxy-6-(hydroxymethyl)tetrahydro-2Hpyran-2-yl)oxy)phenyl)dec-4-en-3-one

(2R,4S,5R)-2-(Acetoxymethyl)-6-(4-(5-hydroxy3-oxodecyl)-2-methoxyphenoxy)tetrahydro2H-pyran-3,4,5-triyl triacetate

5-Hydroxy-1-(3-methoxy-4-((3R,4S,6R)-3,4,5trihydroxy-6-(hydroxymethyl)tetrahydro-2Hpyran-2-yl)oxy)phenyl)decan-3-one
Chemical Structure<smiles>CCOC(=O)/C=C/c1ccc(OC)cc1</smiles>

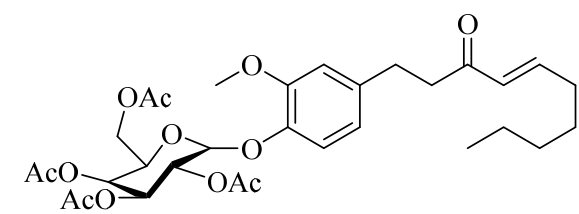<smiles>CCCCC/C=C/C(=O)CCc1ccc(OC2OC(CO)[C@H](O)[C@H](O)[C@H]2O)c(OC)c1</smiles>

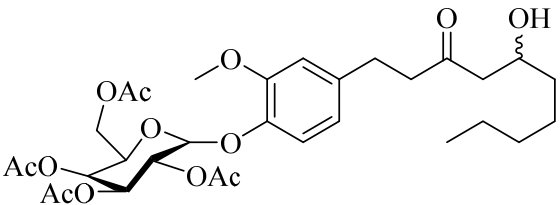<smiles>CCCCC[C@H](O)CC(=O)CCc1ccc(OC2OC(CO)[C@H](O)[C@H](O)[C@H]2O)c(OC)c1</smiles>

Amino acids

Glutamine

Histidine

Glutamic acid

Threonine

Leucine<smiles>NC(=O)CC[C@H](N)C(=O)O</smiles><smiles>N[C@@H](Cc1c[nH]cn1)C(=O)O</smiles><smiles>N[C@@H](CCC(=O)O)C(=O)O</smiles><smiles>C[C@H](O)[C@H](N)C(=O)O</smiles><smiles>CC(C)C[C@H](N)C(=O)O</smiles> 
Table 1. Cont.

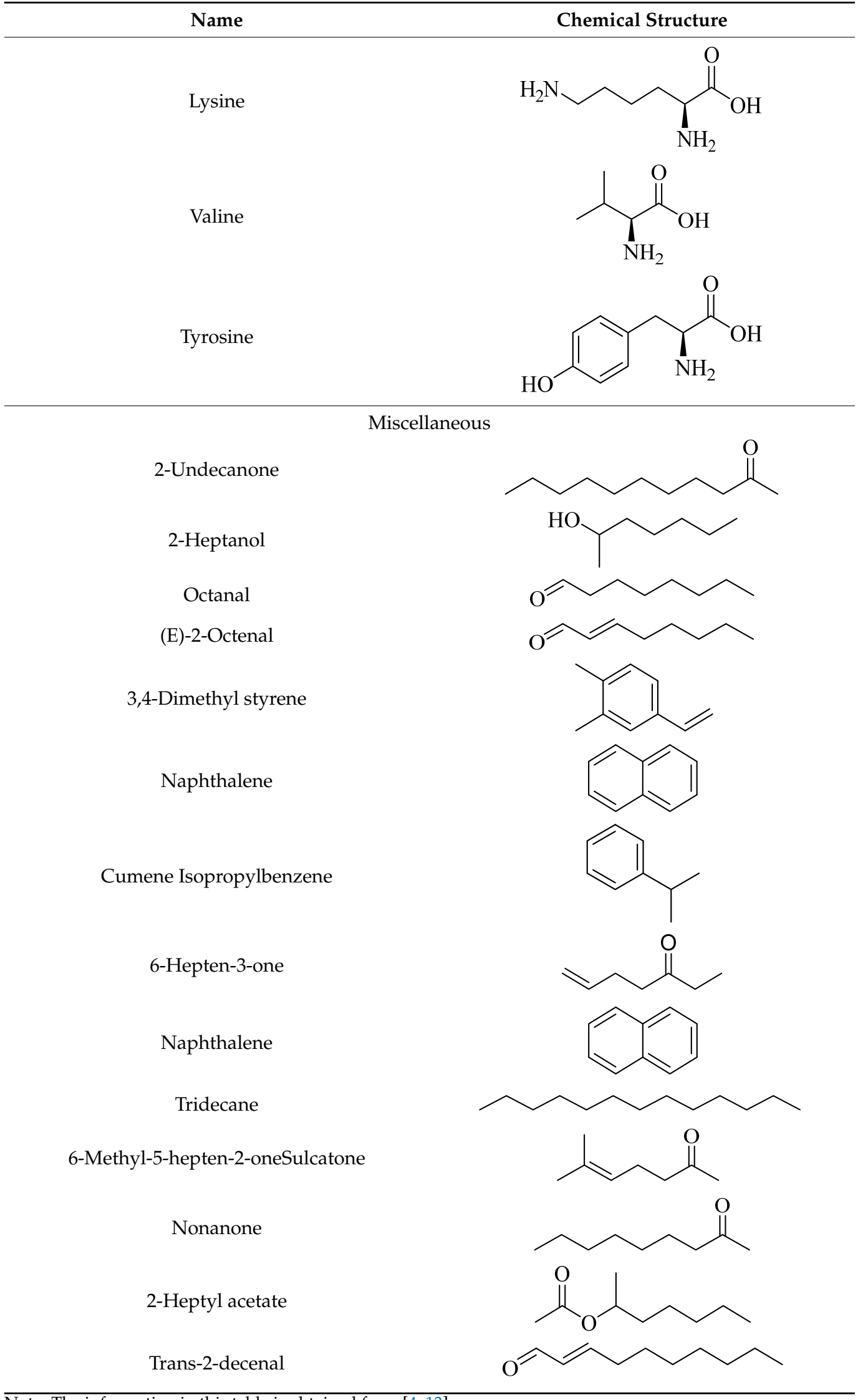




\section{Biosynthesis of Vanilloids}

The vanilloids are biosynthesized from the amino acid phenylalanine, as shown in Figure 2. Shogaols are generated from the dehydration of gingerols' thermally unstable $\beta$-hydroxyl ketone moiety [26,27].

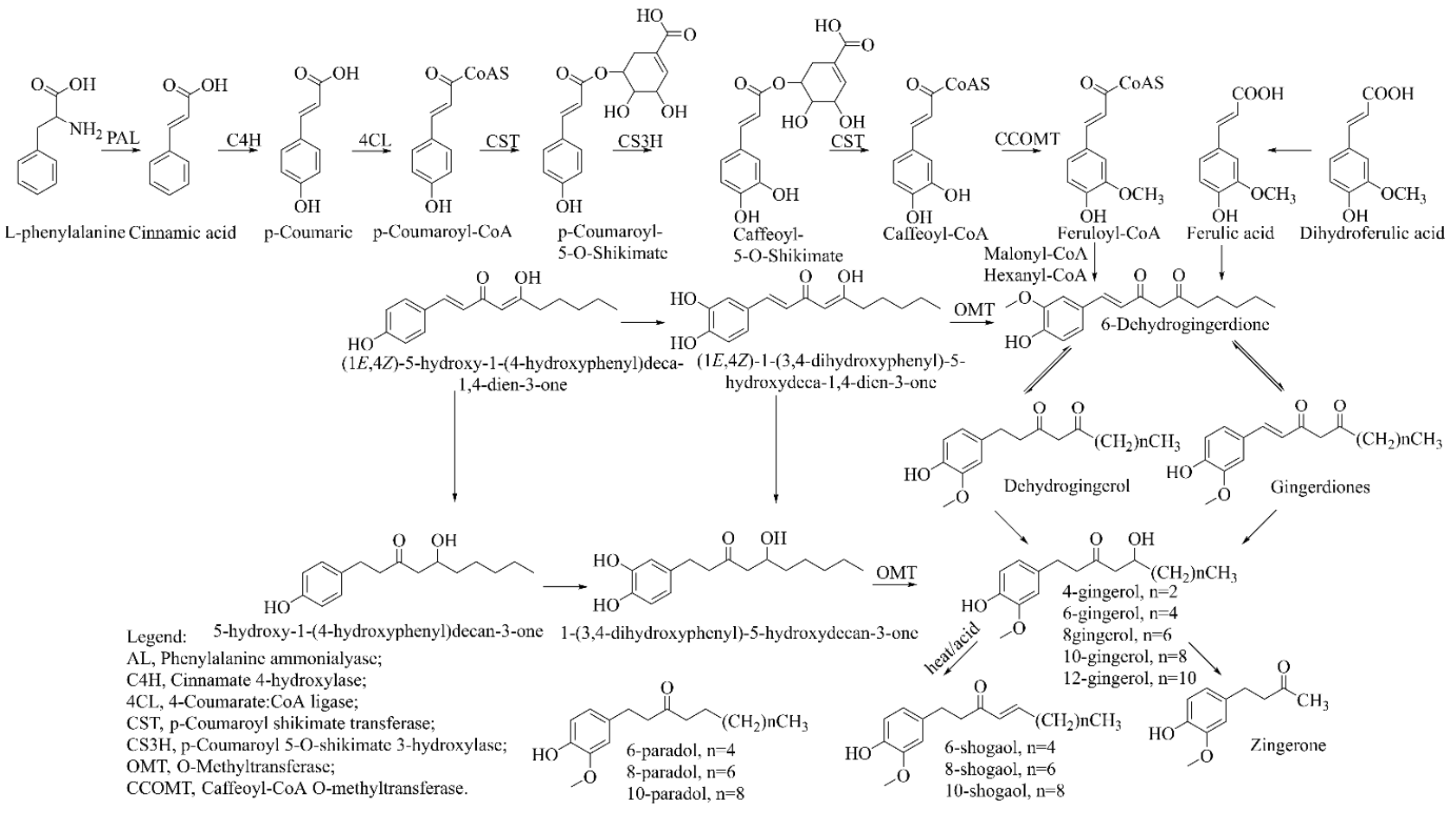

Figure 2. Biosynthetic scheme of ginger pungent compounds [28,29]. The enzymes involved in the biosynthetic pathway to gingerols in ginger are as follows: PAL = Phenylalanine ammonialyase; $\mathrm{C} 4 \mathrm{H}=$ cinnamate 4-hydroxylase; $4 \mathrm{CL}=4$-coumarate: CoA ligase; $\mathrm{CST}=$ p-coumaroyl shikimate transferase; $\mathrm{CS} 3 \mathrm{H}$ = p-coumaroyl 5-O-shikimate 3-hydroxylase; $\mathrm{OMT}$ = O-methyltransferase; CCOMT = caffeoyl-CoA O-methyltransferase.

\section{Biological Activities and Molecular Mechanisms of Red Ginger}

Red ginger is reported to possess a wide range of biological and pharmacological activities. In traditional medicine, it is used for treating headaches, indigestion, nausea, vomiting, and cancer. In addition, it is widely used to treat autoimmune diseases [7], hypertension [30], hypercholesteremia [31], hyperuricemia [32], bacterial infections [1], and cancer [1]. A summary of red ginger's biological activities and molecular mechanisms is given in Table 2 .

Table 2. The biological activities and molecular mechanisms of red ginger.

\begin{tabular}{cccc}
\hline Bioactivity & Mechanism & $\begin{array}{c}\text { Responsible } \\
\text { Constituents }\end{array}$ & Ref. \\
\hline \multirow{2}{*}{ Antimicrobial activity } & $\begin{array}{c}\text { Anti-gram negative } \\
\text { Anti-gram positive } \\
\text { Natural preservative }\end{array}$ & $\beta$-caryophyllene & {$[33]$} \\
& Hyperalgesia $\downarrow$ & Camphene \\
Analgesic activity & $\gamma$-aminobutyric acid $\downarrow$ & $\begin{array}{c}\text { Cineole } \\
\text { NR2B } \downarrow\end{array}$ & Geranial \\
& $\alpha$-amylase & Gingerols & \\
& $\alpha$-glucosidase & shogaols & [37]
\end{tabular}


Table 2. Cont.

\begin{tabular}{|c|c|c|c|}
\hline Bioactivity & Mechanism & $\begin{array}{l}\text { Responsible } \\
\text { Constituents }\end{array}$ & Ref. \\
\hline Anti-inflammatory & $\begin{array}{c}\text { Prostaglandins } \downarrow \\
\text { leukotrienes } \downarrow \\
\text { COX-1 } \downarrow \\
\text { COX-2 } \downarrow \\
5 \text {-LO } \downarrow \\
\text { TNF- } \alpha \downarrow \\
\text { NO } \downarrow \\
\text { iNOS } \downarrow \\
\text { NF-kb } \downarrow \\
\text { TPA } \downarrow \\
\text { ODC } \downarrow\end{array}$ & $\begin{array}{l}\text { 6-gingerol } \\
\text { 6-shogaol } \\
\text { 8-gingerol } \\
\text { 10-gingerol }\end{array}$ & {$[19,38-42]$} \\
\hline Antioxidant & $\begin{array}{l}\text { Donating electrons or a } \\
\text { hydrogen atom to } \\
\text { free radical }\end{array}$ & $\begin{array}{c}\text { Phenolic compounds } \\
\text { Quercetin } \\
\text { 6-shogaol } \\
\text { 8-shogaol } \\
\text { 6-gingerol } \\
\text { 8-gingerol } \\
\text { 10-gingerol }\end{array}$ & {$[19,43-45]$} \\
\hline $\begin{array}{c}\text { Melanogenesis inhibitory } \\
\text { activity }\end{array}$ & $\begin{array}{l}\text { Melanogenesis } \\
\text { inhibitory activity }\end{array}$ & Gingerdione & [25] \\
\hline $\begin{array}{l}\text { Anticancer and antitumor } \\
\text { activity }\end{array}$ & $\begin{array}{l}\text { Angiogenesis and } \\
\text { metastasis }\end{array}$ & $\begin{array}{l}\text { 6-shogaol } \\
\text { 6-gingerol }\end{array}$ & [46-51] \\
\hline Antihyperlipidemic & $\begin{array}{c}\text { LDL-C } \downarrow \\
\text { ACE } \downarrow \\
\text { HDL-C } \downarrow \\
\text { malondialdehyde } \downarrow\end{array}$ & $\begin{array}{c}\text { Gingerol } \\
\text { Shogaol } \\
\text { Gingerdione }\end{array}$ & {$[52,53]$} \\
\hline Anti-hypercholesterolemia & $\begin{array}{c}\mathrm{LDL} \uparrow, \mathrm{HMG}-\mathrm{CoA} \uparrow, \\
\mathrm{HDL} \uparrow\end{array}$ & Phenolic compounds & [54] \\
\hline Antihypertensive & $\begin{array}{c}\text { NO } \uparrow \\
\text { Prostacyclin } \\
\text { Release Ca2+ } \\
\text { Activation of } \\
\text { cGMP-KATP } \\
\text { Stimulation of } \\
\text { muscarinic receptors }\end{array}$ & $\begin{array}{l}\text { 6-gingerol } \\
\text { 6-shogaol } \\
\text { gingerdione }\end{array}$ & {$[30]$} \\
\hline Anti-Alzheimer's disease & $\begin{array}{l}\text { HDAC } \downarrow \text {, Trichostatin } \\
\text { A } \downarrow, \text { MS275 } \downarrow, \text { AChE } \uparrow, \\
\alpha \text {-secretase } \downarrow, \text { A } \beta-42 \downarrow, \\
\beta \text {-secretase } \downarrow, \text { APH1a } \uparrow\end{array}$ & $\begin{array}{l}\text { Flavonoids } \\
\text { Tannins } \\
\text { Alkaloids } \\
\text { 6-shogaol } \\
\text { terpenoids }\end{array}$ & {$[20,53,55-58]$} \\
\hline Androgenic effect & $\begin{array}{l}\text { Pre-leptotene } \uparrow, \\
\text { pachytene } \\
\text { spermatocytes } \uparrow\end{array}$ & $\begin{array}{l}\text { Arginine } \\
\text { Shogaol } \\
\text { Gingerdiol } \\
\text { Gingerol } \\
\text { Zingerone } \\
\text { Zingiber } \\
\end{array}$ & [59-61] \\
\hline Insecticidal activity & $\begin{array}{c}\text { Zingerone and } \\
\text { benzaldehyde dimethyl } \\
\text { thiol acetal }\end{array}$ & $\begin{array}{c}\text { Zingerone } \\
\text { Benzaldehyde } \\
\text { dimethyl thiol acetal }\end{array}$ & [62] \\
\hline Immunomodulatory & $\begin{array}{l}\text { Recover small intestine } \\
\text { mucosa structure of mice } \\
\text { Protective effect on } \\
\text { dopaminergic neurons }\end{array}$ & Phenols & [63] \\
\hline
\end{tabular}




\subsection{Antimicrobial Activity}

Many studies have reported the antimicrobial and antifungal effects of ethanol and methanol extracts of red ginger $[4,64]$. Red ginger was found to be safe and, thus, is used as a food preservative $[65,66]$. Further studies should be carried out to evaluate the molecular mechanisms involved in red ginger's bacterial and fungal resistance. Philip et al. [33] evaluated the antibacterial activity of red ginger against Gram-positive and Gram-negative bacteria using an agar disc diffusion assay. This study found that red ginger showed potent activity in inhibiting the growth and killing of Pseudomonas aeruginosa, Staphylococcus aureus, and Bacillus subtilis. The rhizome oil was moderately active against Bacillus licheniformis, Bacillus spizizenii, Staphylococcus aureus, and Escherichia coli [4].

Red ginger extract has been used as an auxiliary medicine for treating oral infections. Sukandar et al. [64] investigated the antibacterial activity of the combination of red ginger and conventional antimicrobials (amoxicillin, vancomycin, and ketoconazole) against infectious oral microbes. A synergistic interaction between red ginger and conventional antimicrobials was observed against Candida albicans, Staphylococcus aureus, and Streptococcus mutans; therefore, the combinations may help treat orals infections. Another study found that the combination of nisin and red ginger essential oil had a synergistic effect against Bacillus cereus [66]. Studies have shown that red ginger can be used as a preservative for milk and milkfish [65]. Irawan et al. [67] have incorporated red ginger in chitosan films as packaging materials for storing milkfish to increase the shelf life. Rialita et al. [68] optimized antimicrobial products containing red ginger. Red ginger essential oil and Arabic gum in a ratio of 1:3 $(\mathrm{v} / \mathrm{w})$ showed the best microcapsule characteristics.

The primary antimicrobial compounds in red ginger are monoterpenes, of which $\beta$-caryophyllene has predominant antimicrobial activity [4]. The major components of red ginger essential oil showing antimicrobial activity were ar-curcumene, zingiberen, $\beta$-bisabolene, $\beta$-sesquiphellandrene, and camphene [68]. The antimicrobial activity of red ginger essential oil against microbes was in the order Bacillus cereus $>$ Escherichia coli $>$ Salmonella typhimurium $>$ Pseudomonas aeruginosa [66] and Staphylococcus aureus $>$ Escherichia coli $>$ Aspergillus niger $>$ Bacillus cereus $>$ Pseudomonas fluorescens $>$ Salmonella typhimurium. In contrast, the fresh red ginger extract showed stronger activity against Staphylococcus aureus and E. coli [64]. The antibacterial activity of the red ginger extract against Streptococcus mutans is more potent than that of common ginger [69]. Many studies have confirmed the stronger antimicrobial activity against a wide range of bacteria and fungi; thus, it is postulated that it can be used as a natural preservative in the food industry.

\subsection{Analgesic and Antihyperalgesic Activity}

The analgesic activity of red ginger is comparable to that of aspirin [38]. Neuropathic (nerve) pain is caused by damage, dysfunction, or injury of nerves. It affects the patient's quality of life because of its chronicity and intensity. Traditional medicines containing red ginger are used to treat neuropathic pain [70]. Fajrin et al. [36] reported that red ginger oil (200 mg/kg B.W. and $400 \mathrm{mg} / \mathrm{kg}$ B.W.) prolonged the latency time toward the thermal stimulus in male mice, demonstrating antihyperalgesic activity. The activity is mediated via inducing gamma-Aminobutyric acid (GABA) action. GABA balances the action of excitatory and inhibitory neurotransmitters in the central nervous system [71]. GABA suppresses glutamate release and blocks intracellular calcium intake, leading to decreased $\mathrm{NR}_{2} \mathrm{~B}$ activity and pain sensitization [36]. Another mechanism by which red ginger oil exhibits antihyperalgesic activity is the inhibition of prostaglandin synthesis [72,73]. Red ginger oil could also reduce paw thickness via this pathway. However, red ginger did not reverse paw thickness in a CFA-induced inflammation model, suggesting that a complex mechanism might be involved. Fajrin et al. also demonstrated the antihyperalgesic activity of red ginger in diabetic neuropathy, mediated via strengthening the spinal cord [35]. Camphene and cineole were found to possess analgesic activity via reducing the production of reactive oxygen species (ROS), and thus offered spinal cord protection [34,35]. 


\subsection{Antidiabetic Activity}

Red ginger inhibits saccharide hydrolyzing enzymes and, thus, can be used for controlling hyperglycemia in type 2 diabetic patients. Safithri et al. [74] found that a drink composed of red ginger and areca nut had antidiabetic activity in vitro. A formulation containing red betel leaves $(42 \%)$, cinnamon bark $(28 \%)$, red ginger $(15 \%)$, and lime $(15 \%)$ had the highest antidiabetic activity. Deddy et al. used aqueous extracts of red ginger, at a dose of $3 \mathrm{~g}$ per day, to treat type 2 diabetic patients [75].

Oboh et al. [37] reported the $\alpha$-amylase and $\alpha$-glucosidase inhibitory activities of red ginger. Thus, it is postulated that red ginger can be used as a dietary intervention to manage postprandial hyperglycemia in type-2 diabetic patients; however, detailed studies are yet to be done. Vanilloids have been reported to protect liver function in diabetes [76].

\subsection{Anti-Inflammatory Activity}

Many studies have confirmed that chronic inflammation is the underlying cause for many diseases such as allergies, atherosclerosis, cancer, diabetes, infection, obesity, and neurodegeneration $[77,78]$. Red ginger inhibits the synthesis of inflammatory mediators (prostaglandins, cytokines, chemokines, and leukotrienes) via inhibiting the expression of cyclooxygenase (COX)-1, COX-2, and 5-lipoxygenase (5-LO) enzymes [39-41]. In addition, red ginger is reported to inhibit nitric oxide production by inhibiting inducible nitric oxide synthase (iNOS) expression, which is mediated by the attenuation of nuclear factor kappa B (NF-KB)- [38,41]. 6-gingerol inhibits 12-O-tetradecanoyl phorbol acetate 13 (TPA)-induced ornithine decarboxylase (ODC) activity and inflammation [41]. Sang et al. reported that the anti-inflammatory activity of 6-shogaol is more potent than 6-gingerol [42].

\subsection{Antioxidant and Free Radical Scavenging Activity}

Many studies have confirmed red ginger's free radical scavenging activity in different test models [43-45]. The antioxidant activity of red ginger is correlated with the total phenolic content. The antioxidant activity of the phenolic compounds in red ginger is due to their capacity of donating either electrons or hydrogens to free radicals [79]. Jayanudin et al. [43] have developed chitosan microcapsules containing red ginger oleoresin. Ghasemzadeh et al. [45] reported that freeze-dried red ginger has more free radical scavenging activity than vacuum- or oven-dried red ginger. The antioxidant activity is attributed to the presence of flavonoids and vanilloids. Red ginger strongly inhibits NO production in LPS-stimulated J774.1 cells via inhibiting iNOS [80,81]. In addition to scavenging free radicals, red ginger scavenges superoxide and hydroxyl radicals. It also suppresses xanthine oxidase activity, which generates oxygen-containing free radicals. Red ginger also possesses a strong metal-binding capacity to inhibit lipid peroxidation and AAPH-induced DNA damage [19,80]. It is also reported to inhibit $\mathrm{N}$-formyl-methionyl-leucyl-phenylalanine (f-MLP)-induced ROS production in human polymorphonuclear neutrophils (PMN) [19,81].

\subsection{Anticancer and Antitumor Activity}

The anticancer activity of red ginger is mainly due to certain pungent vanilloids [24]. Several mechanisms have been proposed for the anticancer activity of red ginger [82-84]. Response surface methodology was used to optimize the extraction conditions for achieving the highest anticancer activity [24]. Tatsuzaki et al. reported that the highest anticancer activity was observed against human A549, SKOV-3, SK-MEL-2, and HCT15 cancer cells [48]. Dehydrozingerone and its analogues in red ginger exhibited significant cell proliferation inhibitory activity against $\mathrm{KB}$ and A549 cells [85]. 6-gingerol inhibited the proliferation of transgenic mouse ovarian cancer cell lines, $\mathrm{C} 1$ (p53 (-/-), c-myc, K-ras gene), and C2 (p53 (-/-), c-myc, Akt). The acetoxy, alkyl, and $\alpha$ - $\beta$-unsaturated carbonyl groups in the side chain and ortho-dihydroxy group on the aromatic ring in vanilloids play a significant role in the anticancer activity [86]. Vimala et al. [87] reported that red ginger inhibits Epstein-Barr virus early antigen activity in Raji cells, suggesting a role of red ginger in preventing cancer in an early stage of progression. Angiogenesis is a key process in tumor migration (Figure 3), 
and red ginger is reported to inhibit endothelial cell angiogenesis [46,47]. Studies have also shown that 6-gingerol inhibits VEGF- and bFGF-induced cell proliferation, arresting the cell cycle in G1 (by inhibiting human endothelial cyclin D1), which blocks endothelial cells from VEGF [47]. Baliga et al. [88] reported that red ginger inhibits lung metastasis in mice (Figure 3) via antiangiogenic activity and the stimulation of host immunity. These results suggest that red ginger could selectively inhibit the angiogenesis, adhesion, metastasis, and production of MMPs to block the migration of malignant tumors [89]. Multiple mechanisms involved in the anticancer activity of red ginger and vanilloids have been reported elsewhere, including the inhibition of MAPK and PI3K/Akt pathways, inactivation of NF- $\mathrm{B}$ and STAT3, and upregulation of plasminogen activator inhibitor-1 (PAI-1), all of which are participants in the suppression of tumor metastasis [49-51] (Figure 4).

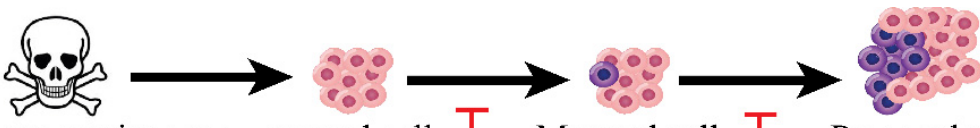

Mutagens carcinogens normal cell $\rceil$ Mutated cell $\rceil$ Preneoplastic

Free radicals

Red ginger

Red ginger
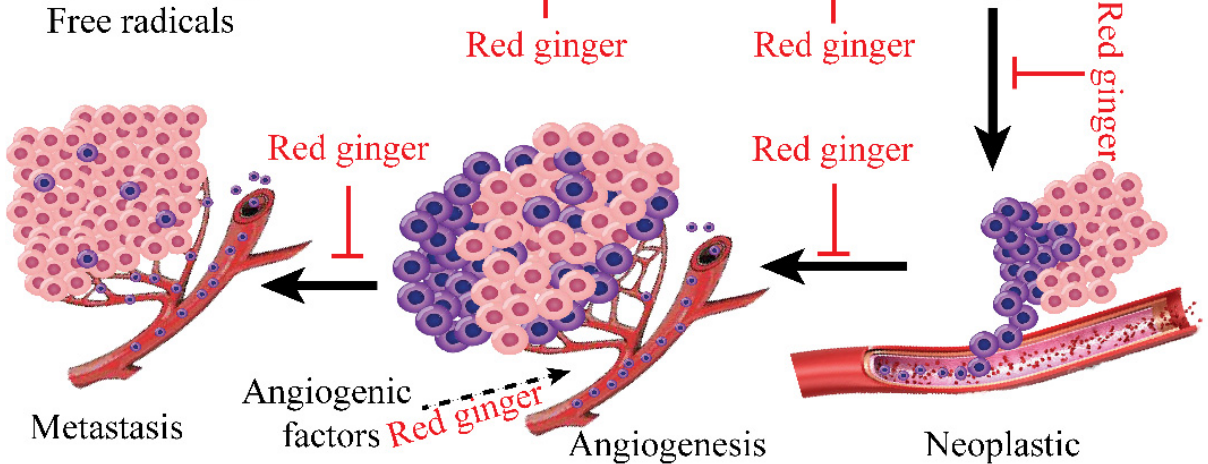

Figure 3. Red ginger inhibits cancer progression, angiogenesis, and metastasis [88].

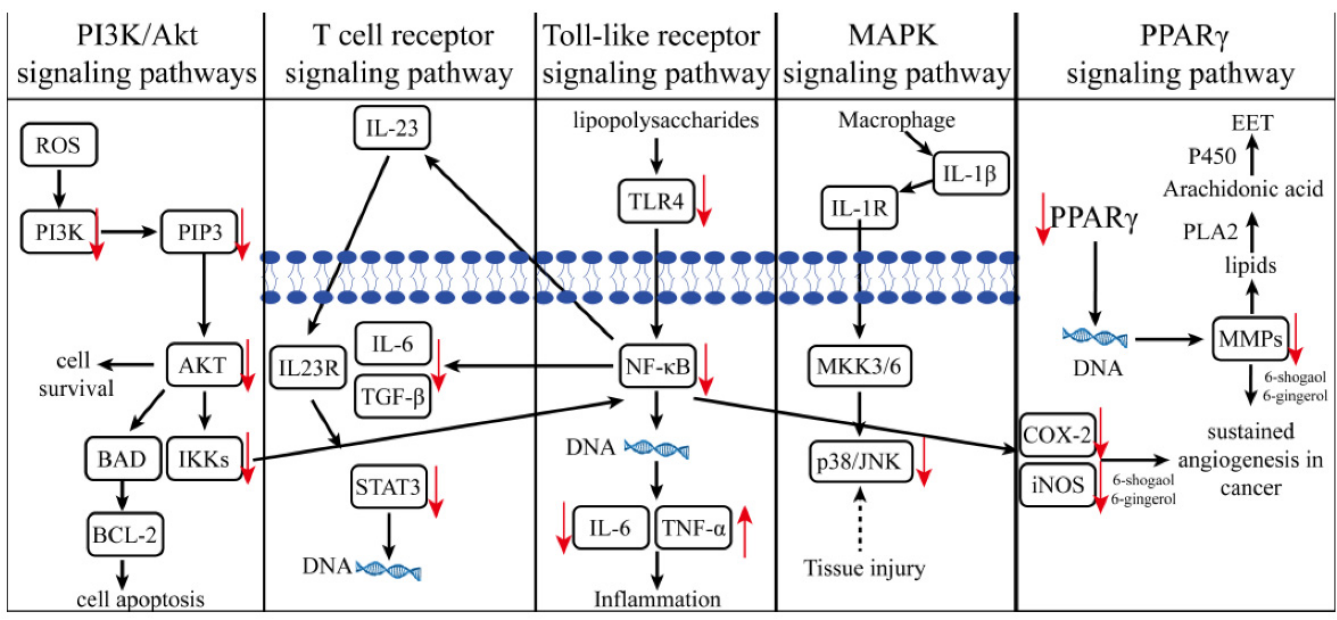

Figure 4. The molecular mechanisms involved in anticancer activity $(\downarrow=$ downregulation/inhibition, $\uparrow=$ upregulation).

\subsection{Antihyperlipidemic, Antihypertensive, and Antihypercholesterolemic Activity}

The antihyperlipidemic, antihypertensive, and antihypercholesterolemic mechanisms of action are as shown in Figure 5. Red ginger oil $(3.2 \mathrm{~mL} / \mathrm{kg}$ for 21 days) reduced lowdensity lipoprotein cholesterol (LDL-C) levels by $12 \%$. The antihyperlipidemic activity of red ginger is attributed to vanilloids and is more potent than that of common ginger [52]. In vitro studies have shown that red ginger aqueous extract $(1: 20 w / v)$ inhibited the actions of Angiotensin-I converting enzyme (ACE), iron(II) ion, and sodium nitroprusside (SNP)induced lipid peroxidation in rats' hearts via reducing malondialdehyde levels. The activity 
of red ginger in this respect is more remarkable than that of common ginger [90]. The antihypertensive activity of red ginger was also demonstrated in cholesterol-fed rats. Red ginger has been reported to reduce malondialdehyde levels in the liver and heart tissues, suggesting that the antihypertensive activity is mediated via inhibiting ACE and lipid peroxidation [52]. Razali et al. [30] demonstrated the antihypertensive activity of red ginger in a SHR (spontaneously hypertensive rat) model. The mechanisms of vascular relaxation involve the release of nitric oxide and prostacyclin, the activation of cGMP-KATP channels, the stimulation of muscarinic receptors, and the stimulation of transmembrane calcium channel or $\mathrm{Ca}^{2+}$ release from intracellular stores. The vanilloids are attributed to the antihypertensive activity of red ginger.

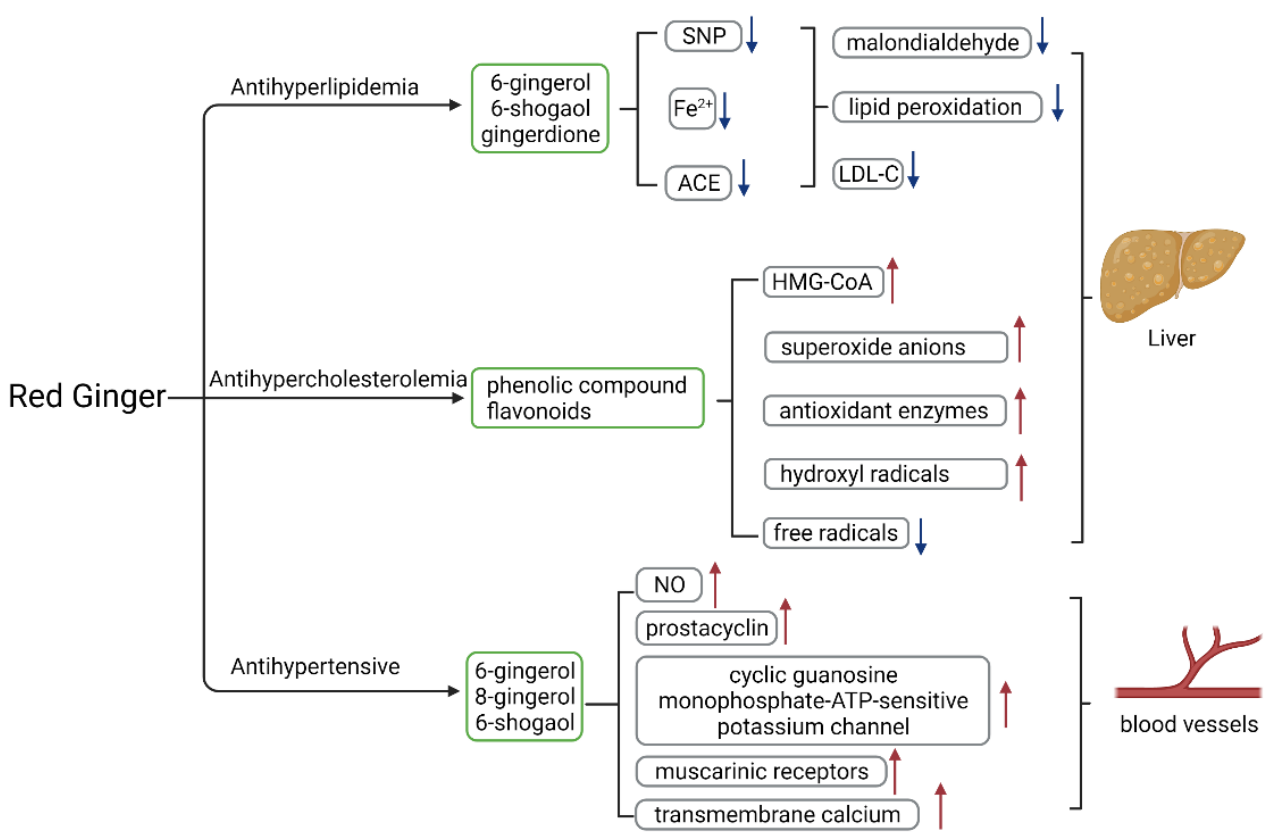

Figure 5. The mechanism of action or red ginger in antihyperlipidemic, antihypertensive, and antihypercholesterolemic activities.

It is well known that red ginger extract contains phenolic compounds, which have been shown to protect against metabolic disorders such as hypercholesterolemia. Hypercholesterolemia results from increased cholesterol levels and increased production of free radicals. Phenolic compounds reduce the risk of hypercholesterolemia by (1) increasing the activity of antioxidant enzymes, (2) decreasing the formation of free radicals, hydroxyl radicals, and superoxide anions, (3) inhibiting lipid peroxidation, and (4) regulating low-density lipoprotein (LDL) receptors [54].

Red ginger is reported to (1) inhibit lipid peroxidation, (2) increase antioxidant enzymes, (3) regulate low-density lipoprotein (LDL) receptors, and (4) regulate 3-hydroxy-3methylglutaryl coenzyme-A receptors (HMG-CoA), which affect cholesterol absorption in the liver [31,91].

\subsection{Neuroprotective Effect}

Oboh et al. have reported the acetylcholinesterase (AChE) inhibitory effect of red ginger in SNP-induced mice [53]. Red ginger has also been reported to protect IMR32 human neuroblastoma, HUVEC cells, and PC12 rat pheochromocytoma cells from amyloidbeta $(A \beta)$ insult $[55,56]$. Amyloid-beta insult is the major cause of Alzheimer's disease. In addition, red ginger also significantly improved cognitive and behavioral impairment and AD-like pathology in mice. These beneficial effects occurred via an increase in $\alpha$-secretase activity and a decrease in cerebral A $\beta-42, \beta$-secretase, APH1a activity, and COX-2-linked neuro-inflammation [57]. 6-Shogoal was the most potent bioactive 
compound responsible for the neuroprotective, neurotrophic, and anti-inflammatory effects of red ginger [58]. The HDAC inhibitory activity of 6-shogaol is comparable to that of Trichostatin A and MS275. 6-shogaol also significantly attenuated various neuroinflammatory responses by inducing HSP70, which is associated with the inhibition of HDAC in cortical astrocytes [20,92].

\subsection{Androgenic Effect}

The vanilloids of red ginger have a potent antioxidant effect [59]. Yang et al. [60] reported that antioxidants could preserve spermatogenesis from the detrimental effects of oxidants. Kanedi et al. [61] also reported that an oral concoction of red ginger extract increases preleptotene and pachytene spermatocytes and spermatids. These studies suggest the androgenic effect of red ginger and its ability to improve sperm quality.

\subsection{Insecticidal Activity}

Mahardika et al. [62] reported the insecticidal and larvicidal activity of red ginger's hexane extract against Aedes albopictus, Aedes aegypti, and Culex quinquefasciatus. The major principal constituents in the extract were zingerone (14.92\%) and benzaldehyde dimethyl thiol acetal (11.61\%). Another study reported the insecticidal activity of red ginger against Spodoptera frugiperda [93] via increasing cysteine protease's enzyme activity.

\subsection{Immunomodulatory Activity}

Red ginger is usually one of the ingredients in immunomodulating supplements. A study showed that the administration of black cincau and red ginger had immunomodulatory effects in infected mice. Exposure of infected mice to red ginger and black cincau can help them to recover the small intestine mucosa structure. This study demonstrates that red ginger extract can have an immunomodulatory effect in Escherichia coli-infected mice [63]. The combination of black cincau, pandan leaves, and red ginger provides a synergic effect, as shown by the increased levels of phenol and antioxidant activity. The combination of black cincau, pandan leaves, and red ginger provides a synergic effect, shown by the increased levels of phenol and antioxidant activity [63]. Due to the presence of phenol in the red ginger supplement, the condition of mice is approaching recovery. A histopathology examination of the small intestine showed that red ginger can improve cells damaged by an intraperitoneal injection of E. coli strain O157 [63].

Red ginger is one of the ingredients in Wedang uwuh (WU, a traditional drink in Southeast Asia). WU has antioxidant activity, can promote blood circulation, and improves immunity. WU extract administered via $27 \mathrm{~mL} / \mathrm{kg}$ injections had a dose-dependent immunomodulatory potential in diabetic rats. The results showed that WU significantly inhibited the expression of pro-inflammatory cytokines and anti-inflammatory cytokines and achieved a balance between pro-inflammatory and anti-inflammatory cytokines that was not significantly different from that of normal controls. This study's results confirm that the use of WU can result in immunomodulatory activity in diabetic rats.

\subsection{Melanogenesis Inhibitory Activity}

Yamauchi et al. [25] reported that the melanogenesis inhibitory activity of red ginger and the activity is due to vanilloids. The activity of gingerols is different from that of shogaols because of the differences in permeability into the cell membranes. The glycosylation of vanilloids improved the activity. There were no reports of the mechanism involved.

\section{Analysis and Quality Control}

\subsection{The Application of Analytical Methods for Assessing Red Ginger's Quality}

Growth conditions influence the chemistry and content of active ingredients in any plant; therefore, developing analytical methods to determine the identity and quality is essential[6]. Two analytical methods, high-performance liquid chromatography coupled with time of flight mass spectrometer (HPLC-TOF-MS) and gas chromatography with a 
mass spectrometer (GC-MS), have been used for the analysis of red ginger $[6,68]$. The essential oil was analyzed using GC-MS. The operational conditions were as follows: helium as a carrier gas, a 5\% HP-5MS phenyl methyl Silox column $(30 \mathrm{~m} \times 250 \mu \mathrm{m} \times 0.25 \mu \mathrm{m})$, column temperature set to $50{ }^{\circ} \mathrm{C}$, pressure of $7.0699 \mathrm{psi}$, flow rate of $1 \mathrm{~mL} / \mathrm{min}$, velocity of $36.262 \mathrm{~cm} / \mathrm{s}$, column flow of $1 \mathrm{~mL} /$ minute, split ratio of 25:1, and split inlet temperature of $250{ }^{\circ} \mathrm{C}$. The major components of essential oil are monoterpenes, sesquiterpenes, alcohols, aldehydes, and organic acids. Monoterpenes and sesquiterpenes have strong antimicrobial activity [4]. A total of 54 compounds in fresh red ginger essential oil were reported, out of which the major components are Z-citral $(23.332 \%)$, citral $(18.87 \%), 1,8$-cineole $(12.18 \%)$, camphene $(11.87 \%)$, geranyl acetate $(3.82 \%)$, linalool $(2.88 \%), \alpha$-pinene $(2.6 \%)$, 5-hepten-2-one, 6-methyl-(2.32\%), ar-curcumene (2.06\%), and $\alpha$-terpineol (2.05\%) [66]. In another study, Nissa et al. reported 20 compounds, of which $81.9 \%$ were monoterpenes, and geranial $(11.97 \%)$ and 1.8 -cineole $(15.10 \%)$ were predominant. The predominant sesquiterpene is $\alpha \mathrm{r}$-curcumene $(16.86 \%)$. The other components had concentrations of less than $10 \%$ [9]. The difference in the essential oil composition could be due to variations in climate, soil, growth conditions, harvest time, and the rhizomes' age [9]. The major components in essential oil were found to be $\alpha$-zingiberene, $\alpha$-curcumene, $\beta$-bisabolene, and $\beta$-sesquiphellandrene.

\subsection{Chemical Fingerprint Analysis}

The chemical fingerprint analysis was reported using HPLC-TOF-MS[6]. The optimum chromatographic conditions were: source voltage, $+4.5 \mathrm{kV}$ (positive ion mode) or $-3.5 \mathrm{kV}$ (negative ion mode); capillary temperature, $200^{\circ} \mathrm{C}$; and nebulizer gas flow rate, $1.5 \mathrm{~mL} / \mathrm{min}$. The mass spectrometer was operated in positive and negative ion modes, scanning from 150 to $1500 \mathrm{~m} / z$. A Waters Atlantis T3 column $(2.1 \mathrm{~mm} \times 150 \mathrm{~mm}, 5 \mu \mathrm{m})$ was used and the column temperature was maintained at $40{ }^{\circ} \mathrm{C}$. The mobile phase was a binary eluent of (A) $5 \mathrm{mM}\left(\mathrm{NH}_{4}\right) \mathrm{OAc}$ solution and (B) $\mathrm{CH}_{3} \mathrm{CN}$ under the following gradient conditions: 0-30 min, linear gradient from $10 \%$ to $100 \% \mathrm{~B} ; 30-40 \mathrm{~min}$, isocratic at $100 \% \mathrm{~B}$. The flow rate was $0.2 \mathrm{~mL} / \mathrm{min}$.

\section{Medicinal Products}

Red ginger has gained traction, especially in Asia, where it is known for its medicinal effects: dispelling wind from the body, relieving indigestion, improving blood circulation, and relieving inflammation. The beneficial effects attributed to the constituents of red ginger have occasioned the creation of various medicinal products. In Southeast Asia, red ginger is locally known as halia bara, halia merah, or jahe merah. Currently, the red ginger products marketed in Southeast Asia include foodstuffs such as dried ginger pieces and pickled ginger, and red ginger extracts in instant beverages such as tea and coffee. Furthermore, red ginger extracts are also added to body lotions, creams, ointments, and capsules.

\section{Our Perspectives}

Our research group has avidly studied ginger, its constituents, and their pharmacological properties. We prepared this review to present a concise summary of the information on red ginger gathered from the scientific literature thus far. We believe that this will be useful to researchers who are working on ginger, natural products, functional foods, and even ethnomedicine. From our perspective, based on our experience with ginger variants, the following are the main differences between red ginger and common ginger. They are: (1) they differ in color and size; (2) fresh red ginger is more pungent than fresh common ginger; (3) upon drying, red ginger turns black, while common ginger does not; (4) dried red ginger is much harder than dried common ginger; (5) the constituents are reported to be the same in both gingers; however, red ginger is reported to be more biologically active; (6) a few studies have reported that the active constituents (gingerols and shogaols) are higher in red ginger than in common ginger; (7) it is very difficult to distinguish these two variants based on the chemical composition via simple analytical techniques using HPLC 
and GC instruments; (8) there have been no studies characterizing the constituent that gives red ginger its color; (9) there are no studies on why red ginger is hotter than common ginger; and (10) there are no detailed studies that compare the bioactivities of red ginger and common ginger under the same experimental conditions that clearly explain why red ginger is preferred in ethnomedicine, etc.

To date, conclusions on the differences between red ginger and common ginger have yet to be drawn. We strongly believe that it is still worth scientifically exploring the effects of red ginger. The research should be carried out on a standardized extract rather than individual compounds in the physiologically relevant models and molecular mechanisms. It is well established that vanilloids are unique compounds in all ginger variants. Based on our experience with ginger, we believe that red ginger's chemistry (both primary and secondary metabolites) is different from common ginger, giving rise to a difference in the hotness and biological activities. In our opinion, the plant preparations (consisting of active and inactive constituents) in ethnomedicine are equivalent to modern formulations (consisting of active pharmaceutical ingredients (API) and excipients). It is well known that excipients in a formulation influence the bioactivity of API. Similarly, the inactive constituents in a plant extract also influence the bioactivity of the active constituents.

Red ginger extracts are scientifically validated for their beneficial effects in inflammatory diseases, metabolic diseases, cancer, neurological diseases, and cardiovascular diseases. Research in these disease areas is still a priority for many researchers, institutions, and the pharmaceutical industry. Thus, like herbal medicine, we argue that red ginger has a lot of potential to provide breakthroughs for these diseases. The ginger extract, ginger oil, and zingerone (pungent components of ginger) are included in DrugBank (https:/ / go.drugbank.com/drugs, accessed on 20 November 2021), which indicates the potential for ginger to be used in modern medicine for therapeutic purposes.

\section{Conclusions}

This review summarizes the latest research progress on red ginger regarding its chemistry, ethnomedicinal uses, biological activities, molecular mechanism, and analytical methods. We have provided our perspectives on the value of red ginger in metabolic and neurological diseases. The vanilloids are unique to ginger, and are stable in ginger. However, upon isolation in pure form, they are not stable at room temperature. Although vanilloids are simple molecules, their synthesis is still challenging. Thus, further exploring the potential of red ginger in medicine is essential. Many herbal formulations containing red ginger are famous in various traditional systems of medicine. Many scientific studies worldwide have proven the efficacy of red ginger in a wide array of diseases-metabolic, neurological, cardiovascular, infectious, and cancer. Despite red ginger being relatively safe $[94,95]$, consuming large amounts of ginger can cause hypoglycemia and spontaneous miscarriage $[96,97]$. However, there are no reports of clinical studies om red ginger.

Author Contributions: S.Z., X.K. and H.Z. collected the literature, and drafted the manuscript. S.Z., K.-K.M. and M.R.P. edited and revised the manuscript. M.R.P. and M.K.B. secured the research grant. All authors have read and agreed to the published version of the manuscript.

Funding: The authors would like to thank the Ministry of Higher Education, Malaysia (Project number: FRGS/1/2018/SKK10/IMU/03/3), and the International Medical University (Project ID: PHMS1/2019(01)) for financial assistance with this project.

Conflicts of Interest: The authors declare no conflict of interest.

\section{References}

1. Syafitri, D.M.; Levita, J.; Mutakin, M.; Diantini, A. A Review: Is Ginger (Zingiber officinale var. Roscoe) Potential for Future Phytomedicine? Indones. J. Appl. Sci. 2018, 8, 30. [CrossRef]

2. Setyawan, A.D.; Wiryanto, W.; Suranto, S.; Bermawie, N. Short Communication: Variation in isozymic pattern of germplasm from three ginger (Zingiber officinale) varieties. Nusant. Biosci. 1970, 6, 113. [CrossRef] 
3. Safitri, A.R.; Evanuarini, H.; Thohari, I. The Potential of Local Ginger as Antioxidant on Full Fat Mayonnaise. J. Ilmu dan Teknol. Has. Ternak 2019, 14, 90-98. [CrossRef]

4. Sivasothy, Y.; Chong, W.K.; Hamid, A.; Eldeen, I.M.; Sulaiman, S.F.; Awang, K. Essential oils of Zingiber officinale var. rubrum Theilade and their antibacterial activities. Food Chem. 2011, 124, 514-517. [CrossRef]

5. Kusumawati, N.; Anggarani, M.A.; Rusijono; Setiarso, P.; Muslim, S. Product standarization of ginger (Zingiber officinale rosc.) and red ginger (Zingiber officinale var. rubrum) simplicia through washing time, slice thickness and raw materials drying process optimization. Int. J. Adv. Sci. Eng. Inf. Technol. 2017, 7, 15-21. [CrossRef]

6. Nishidono, Y.; Saifudin, A.; Nishizawa, M.; Fujita, T.; Nakamoto, M.; Tanaka, K. Identification of the chemical constituents in Ginger (Zingiber officinale) responsible for thermogenesis. Nat. Prod. Commun. 2018, 13, 869-873. [CrossRef]

7. Nordin, N.I.; Gibbons, S.; Perrett, D.; Mageed, R.A.; Nafiah, M.A. Immunomodulatory Effects of Roscoe var. (Halia Bara) ON Inflammatory Responses Relevant to Psoriasis. Open Conf. Proc. J. 2015, 4, 76. [CrossRef]

8. Koike, N.; Yoo, S.H.; Huang, H.C.; Kumar, V.; Lee, C.; Kim, T.K.; Takahashi, J.S. Transcriptional architecture and chromatin landscape of the core circadian clock in mammals. Science 2012, 338, 349-354. [CrossRef]

9. Rinanda, T.; Isnanda, R.P. Zulfitri Chemical analysis of red ginger (Zingiber officinale Roscoe var rubrum) essential oil and its anti-biofilm activity against candida albicans. Nat. Prod. Commun. 2018, 13, 15-18. [CrossRef]

10. Sri Nurestri Abd Malek, H. The Essential Oils of Zingiber officinale Variants. Malaysian J. Sci. 1970, $24,37-43$.

11. Ghasemzadeh, A.; Jaafar, H.Z.E.; Karimi, E.; Ibrahim, M.H. Combined effect of CO2 enrichment and foliar application of salicylic acid on the production and antioxidant activities of anthocyanin, flavonoids and isoflavonoids from ginger. BMC Complement. Altern. Med. 2012, 12, 229. [CrossRef]

12. Kakadiya, R.; Wu, Y.C.; Dong, H.; Kuo, H.H.; Yih, L.H.; Chou, T.C.; Su, T.L. Novel 2-Substituted quinolin-4-yl-benzenesulfonate derivatives: Synthesis, antiproliferative activity, and inhibition of cellular tubulin polymerization. ChemMedChem 2011, 6 1119-1129. [CrossRef]

13. Ghasemzadeh, A.; Jaafar, H.Z.E.; Karimi, E.; Ashkani, S. Changes in nutritional metabolites of young ginger (Zingiber officinale roscoe) in response to elevated carbon dioxide. Molecules 2014, 19, 16693-16706. [CrossRef]

14. MohdDuran, A.; Rashid, K.; Ibrahim, H.; Jalil, M.; Mohd Yusof, Y.; Shamzir Kamal, S.; Efzueni, S.; Farzinebrahimi, R. Toxic trace elements in selected edible rhizomes of medicinal plants using INAA and ICP-MS techniques. Int. J. Complement. Altern. Med. 2017, 6, 1-4. [CrossRef]

15. Ghasemzadeh, A.; Jaafar, H.Z.E.; Rahmat, A. Antioxidant Activities, Total Phenolics and Flavonoids Content in Two Varieties of Malaysia Young Ginger (Zingiber officinale Roscoe). Molecules 2010, 15, 4324-4333. [CrossRef]

16. Ghasemzadeh, A.; Jaafar, H.Z.E.; Karimi, E. Involvement of salicylic acid on antioxidant and anticancer properties, anthocyanin production and chalcone synthase activity in ginger (Zingiber officinale roscoe) varieties. Int. J. Mol. Sci. 2012, 13, 14828-14844. [CrossRef]

17. Ghasemzadeh, A.; Jaafar, H.Z.E. Effect of $\mathrm{CO} 2$ enrichment on synthesis of some primary and secondary metabolites in ginger (Zingiber officinale Roscoe). Int. J. Mol. Sci. 2011, 12, 1101-1114. [CrossRef]

18. Semwal, R.B.; Semwal, D.K.; Combrinck, S.; Viljoen, A.M. Gingerols and shogaols: Important nutraceutical principles from ginger. Phytochemistry 2015, 117, 554-568. [CrossRef]

19. Dugasani, S.; Pichika, M.R.; Nadarajah, V.D.; Balijepalli, M.K.; Tandra, S.; Korlakunta, J.N. Comparative antioxidant and anti-inflammatory effects of [6]-gingerol, [8]-gingerol, [10]-gingerol and [6]-shogaol. J. Ethnopharmacol. 2010, 127, 515-520. [CrossRef]

20. Maged, R.; Nordin, N.; Abdulla, M. Anti-inflammatory effects of Zingiber officinale roscoe involve suppression of nitric oxide and prostaglandin E2 production. Zanco J. Med. Sci. 2013, 17, 349-356. [CrossRef]

21. Baliga, M.S.; Jagetia, G.C.; Rao, S.K.; Babu, S.K. Evaluation of nitric oxide scavenging activity of certain spices in vitro: A preliminary study. Nahrung-Food 2003, 47, 261-264. [CrossRef]

22. Tjendraputra, E.; Tran, V.H.; Liu-Brennan, D.; Roufogalis, B.D.; Duke, C.C. Effect of ginger constituents and synthetic analogues on cyclooxygenase-2 enzyme in intact cells. Bioorg. Chem. 2001, 29, 156-163. [CrossRef]

23. He, X.; Bernart, M.W.; Lian, L.; Lin, L. High-performance liquid chromatography-electrospray mass spectrometric analysis of pungent constituents of ginger. J. Chromatogr. A 1998, 796, 327-334. [CrossRef]

24. Ghasemzadeh, A.; Jaafar, H.Z.E.; Rahmat, A. Optimization protocol for the extraction of 6-gingerol and 6-shogaol from Zingiber officinale var. rubrum Theilade and improving antioxidant and anticancer activity using response surface methodology. BMC Complement. Altern. Med. 2015, 15, 258. [CrossRef]

25. Yamauchi, K.; Natsume, M.; Yamaguchi, K.; Batubara, I.; Mitsunaga, T. Structure-activity relationship for vanilloid compounds from extract of Zingiber officinale var rubrum rhizomes: Effect on extracellular melanogenesis inhibitory activity. Med. Chem. Res. 2019, 28, 1402-1412. [CrossRef]

26. Mukkavilli, R.; Yang, C.; Tanwar, R.S.; Ghareeb, A.; Luthra, L.; Aneja, R. Absorption, metabolic stability, \& pharmacokinetics of ginger phytochemicals. Molecules 2017, 22, 553. [CrossRef]

27. Bhattarai, S.; Tran, V.H.; Duke, C.C. Stability of [6]-gingerol and [6]-shogaol in simulated gastric and intestinal fluids. J. Pharm. Biomed. Anal. 2007, 45, 648-653. [CrossRef] [PubMed] 
28. Ramirez-Ahumada, M.C.; Timmermann, B.N.; Gang, D.R. Biosynthesis of curcuminoids and gingerols in turmeric (Curcuma longa) and ginger (Zingiber officinale): Identification of curcuminoid synthase and hydroxycinnamoyl-CoA thioesterases. Phytochemistry 2006, 67, 2017-2029. [CrossRef] [PubMed]

29. Macleod, I.; Whiting, D.A. Stages in the biosynthesis of [6]-gingerol in Zingiber officinale. J. Chem. Soc. Chem. Commun. 1979, 79, 1152-1153. [CrossRef]

30. Razali, N.; Dewa, A.; Asmawi, M.Z.; Mohamed, N.; Manshor, N.M. Mechanisms underlying the vascular relaxation activities of Zingiber officinale var. rubrum in thoracic aorta of spontaneously hypertensive rats. J. Integr. Med. 2020, 18, 46-58. [CrossRef]

31. Nirvana, S.J.; Widiyani, T.; Budiharjo, A. Antihypercholesterolemia activities of red ginger extract (Zingiber officinale Roxb. var rubrum) on wistar rats. In Proceedings of the IOP Conference Series: Materials Science and Engineering, Chennai, India, 16-17 September 2020; Volume 858, p. 012025.

32. Hariyanto, I.H.; Indri, K.; Saragih, N. Antihyperuricemia activity from methanol extract of red ginger rhizomes (Zingiber officinale Rosc. var rubrum) towards white male rat wistar strain. Int J Pharm Teach Pr. 2013, 4, 540.

33. Philip, K.; Malek, S.N.A.; Sani, W.; Shin, S.K.; Kumar, S.; Lai, H.S.; Serm, L.G.; Rahman, S.N.S.A. Antimicrobial activity of some medicinal plants from Malaysia. Am. J. Appl. Sci. 2009, 6, 1613-1617. [CrossRef]

34. Tiwari, M.; Kakkar, P. Plant derived antioxidants-Geraniol and camphene protect rat alveolar macrophages against t-BHP induced oxidative stress. Toxicol. Vitr. 2009, 23, 295-301. [CrossRef] [PubMed]

35. Fajrin, F.A.; Imandasari, N.; Barki, T.; Sulistyaningrum, G.; Afifah; Kristiningrum, N.; Puspitasari, E.; Holidah, D. The activity of red ginger oil in antioxidant study in vitro and antihyperalgesia effect in alloxan-induced painful diabetic neuropathy in mice. Thai J. Pharm. Sci. 2019, 43, 69-75.

36. Fajrin, F.A.; Purwandhono, A.; Christianty, F.M.; Sulistyaningrum, G.D.; Afifah; Imandasari, N.; Barki, T. Antihyperalgesia potency of Zingiber officinale var. Rubrum in inflammatory and neuropathy-induced chronic pain condition in mice. Pak. J. Pharm. Sci. 2019, 32, 1663-1669.

37. Adedayo, B.C.; Ademiluyi, A.O.; Oboh, G.; Akindahunsi, A.A. Interaction of aqueous extracts of two varieties of Yam tubers (Dioscorea spp) on some key enzymes linked to type 2 diabetes in vitro. Int. J. Food Sci. Technol. 2012, 47, 703-709. [CrossRef]

38. Shimoda, H.; Shan, S.-J.; Tanaka, J.; Seki, A.; Seo, J.-W.; Kasajima, N.; Tamura, S.; Ke, Y.; Murakami, N. Anti-Inflammatory Properties of Red Ginger (Zingiber officinale var. Rubra) Extract and Suppression of Nitric Oxide Production by Its Constituents. J. Med. Food 2010, 13, 156-162. [CrossRef]

39. Grzanna, R.; Lindmark, L.; Frondoza, C.G. Ginger-An Herbal Medicinal Product with Broad Anti-Inflammatory Actions J. Med. Food 2005, 8, 125-132. [CrossRef] [PubMed]

40. Aktan, F.; Henness, S.; Tran, V.; Duke, C.; Roufogalis, B.; Ammit, A. Gingerol Metabolite and a Synthetic Analogue Capsarol ${ }^{\mathrm{TM}}$ Inhibit Macrophage NF-кB-Mediated iNOS Gene Expression and Enzyme Activity. Planta Med. 2006, 72, 727-734. [CrossRef]

41. Park, K.K.; Chun, K.S.; Lee, J.M.; Lee, S.S.; Surh, Y.J. Inhibitory effects of [6]-gingerol, a major pungent principle of ginger, on phorbol ester-induced inflammation, epidermal ornithine decarboxylase activity and skin tumor promotion in ICR mice. Cancer Lett. 1998, 129, 139-144. [CrossRef]

42. Sang, S.; Hong, J.; Wu, H.; Liu, J.; Yang, C.S.; Pan, M.H.; Badmaev, V.; Ho, C.T. Increased growth inhibitory effects on human cancer cells and anti-inflammatory potency of shogaols from Zingiber officinale relative to gingerols. J. Agric. Food Chem. 2009, 57, 10645-10650. [CrossRef] [PubMed]

43. Jayanudin; Fahrurrozi, M.; Wirawan, S.K. Rochmadi Antioxidant activity and controlled release analysis of red ginger oleoresin (Zingiber officinale var rubrum) encapsulated in chitosan cross-linked by glutaraldehyde saturated toluene. Sustain. Chem. Pharm. 2019, 12, 100132. [CrossRef]

44. Levita, J.; Syafitri, D.; Supu, R.; Mutakin, M.; Megantara, S.; Febrianti, M.; Diantini, A. Pharmacokinetics of 10-gingerol and 6-shogaol in the plasma of healthy subjects treated with red ginger (Zingiber officinale var. Rubrum) suspension. Biomed. Reports 2018, 9, 474-482. [CrossRef] [PubMed]

45. Ghasemzadeh, A.; Jaafar, H.Z.E.; Rahmat, A. Variation of the phytochemical constituents and antioxidant activities of Zingiber officinale var. rubrum Theilade associated with different drying methods and polyphenol oxidase activity. Molecules 2016, 21, 780. [CrossRef]

46. Tsai, T.; Tsai, P.; Ho, S. Antioxidant and anti-inflammatory activities of several commonly used spices. J. Food Sci. 2005, 70, C93-C97. [CrossRef]

47. Kim, E.-C.; Min, J.-K.; Kim, T.-Y.; Lee, S.-J.; Yang, H.-O.; Han, S.; Kim, Y.-M.; Kwon, Y.-G. [6]-Gingerol, a pungent ingredient of ginger, inhibits angiogenesis in vitro and in vivo. Biochem. Biophys. Res. Commun. 2005, 335, 300-308. [CrossRef]

48. Tatsuzaki, J.; Bastow, K.F.; Nakagawa-Goto, K.; Nakamura, S.; Itokawa, H.; Lee, K.-H. Dehydrozingerone, chalcone, and isoeugenol analogues as in vitro anticancer agents. J. Nat. Prod. 2006, 69, 1445-1449. [CrossRef] [PubMed]

49. Ling, H.; Yang, H.; Tan, S.H.; Chui, W.K.; Chew, E.H. 6-Shogaol, an active constituent of ginger, inhibits breast cancer cell invasion by reducing matrix metalloproteinase-9 expression via blockade of nuclear factor- $\mathrm{kB}$ activation. Br. J. Pharmacol. 2010, 161, 1763-1777. [CrossRef]

50. Weng, C.J.; Wu, C.F.; Huang, H.W.; Ho, C.T.; Yen, G.C. Anti-invasion effects of 6-shogaol and 6-gingerol, two active components in ginger, on human hepatocarcinoma cells. Mol. Nutr. Food Res. 2010, 54, 1618-1627. [CrossRef]

51. Weng, C.J.; Chou, C.P.; Ho, C.T.; Yen, G.C. Molecular mechanism inhibiting human hepatocarcinoma cell invasion by 6-shogaol and 6-gingerol. Mol. Nutr. Food Res. 2012, 56, 1304-1314. [CrossRef] 
52. Akinyemi, A.J.; Ademiluyi, A.O.; Oboh, G. Inhibition of Angiotensin-1-Converting Enzyme Activity by Two Varieties of Ginger (Zingiber officinale ) in Rats Fed a High Cholesterol Diet. J. Med. Food 2014, 17, 317-323. [CrossRef]

53. Oboh, G.; Ademiluyi, A.O.; Akinyemi, A.J. Inhibition of acetylcholinesterase activities and some pro-oxidant induced lipid peroxidation in rat brain by two varieties of ginger (Zingiber officinale). Exp. Toxicol. Pathol. 2012, 64, 315-319. [CrossRef]

54. Sunarti, S.; Fachrial, E.; Harahap, U.; Delyuzar, D.; Widyawati, T.; Lubis, L.D. Hepatoprotective effect of red ginger rhizome extract in deep frying oil-fed male wistar rats. Universa Med. 2017, 36, 228. [CrossRef]

55. Kim, D.S.H.L.; Kim, J.Y. Side-chain length is important for shogaols in protecting neuronal cells from $\beta$-amyloid insult. Bioorganic Med. Chem. Lett. 2004, 14, 1287-1289. [CrossRef] [PubMed]

56. Kim, D.S.H.L.; Kim, D.S.; Oppel, M.N. Shogaols from Zingiber officinale protect IMR32 human neuroblastoma and normal human umbilical vein endothelial cells from $\beta$-amyloid(25-35) insult. Planta Med. 2002, 68, 375-376. [CrossRef] [PubMed]

57. Halawany, A.M.; Sayed, N.S.; Abdallah, H.M.; Dine, R.S. Protective effects of gingerol on streptozotocin-induced sporadic Alzheimer's disease: Emphasis on inhibition of $\beta$-amyloid, COX-2, alpha-, beta-secretases and APH1a. Sci. Rep. $2017,7,2902$. [CrossRef] [PubMed]

58. Ha, S.K.; Moon, E.; Ju, M.S.; Kim, D.H.; Ryu, J.H.; Oh, M.S.; Kim, S.Y. 6-Shogaol, a ginger product, modulates neuroinflammation: A new approach to neuroprotection. Neuropharmacology 2012, 63, 211-223. [CrossRef]

59. Nurhanifah, N.; Sutyarso, S.; Kanedi, M.; Busman, H. Aggressiveness and Libido of Male Mus musculus L. in Ethanol Extract of Red Ginger (Zingiber officinale Roxb. var. Rubrum). J. Ilm. Biol. Eksperimen dan Keanekaragaman Hayati 2019, 6, 8-14. [CrossRef]

60. Hoe, S.Y.; Dong, K.H.; Jung, R.K.; Jae, C.S. Effects of $\alpha$-tocopherol on cadmium-induced toxicity in rat testis and spermatogenesis. J. Korean Med. Sci. 2006, 21, 445-451. [CrossRef]

61. Sutyarso; Muhartono; Susianti; Busman, H.; Kanedi, M. Testicular function of rats treated with water extract of red ginger (Zingiber officinale var. rubrum) combined with zinc. J. Food Nutr. Res. 2016, 4, 157-162. [CrossRef]

62. Mahardika, R.W.; Ibrahim, H.; Nurulhusna, A.H.; Awang, K. Efficacy of four species of Zingiberaceae extract against vectors of dengue, chikungunya and filariasis. Trop. Biomed. 2017, 34, 375-387.

63. Widyaningsih, T.D.; Martati, E.; Lukitasari, D.M. Immunomodulatory effects of black cincau (Mesona Palustris BL.) supplement on Escherichia Coli strain O157-infected mice. Asian J. Pharm. Clin. Res. 2017, 10, 326-330. [CrossRef]

64. Sukandar, E.Y.; Kurniati, N.F.; Wikaningtyas, P.; Agprikani, D. Antibacterial interaction of combination of ethanolic extract of Zingiber officinale var rubrum rhizome, Boesenbergia pandurata rhizome, and Stevia rebaudiana leaves with certain antibiotics against infectious mouth microbial. Asian J. Pharm. Clin. Res. 2016, 9, 311-314.

65. Krisanti, E.; Astuty, R.M.; Mulia, K. Microencapsulation of oleoresin from red ginger (Zingiber officinale var. Rubrum) in chitosan and alginate for fresh milk preservatives. In AIP Conference Proceedings; AIP Publishing LLC: Melville, NY, USA, 2017; Volume 1817, p. 030016.

66. Nissa, A.; Utami, R.; Sari, A.M.; Nursiwi, A. Combination effect of nisin and red ginger essential oil (Zingiber officinale var. rubrum) against foodborne pathogens and food spoilage microorganisms. In AIP Conference Proceedings; AIP Publishing LLC: Melville, NY, USA, 2018; Volume 2014, p. 020023.

67. Irawan, A.; Barleany, D.R.; Jayanudin; Yulvianti, M.; Maulana, R.C.; Fitriani, L.Y. Chitosan active films containing red ginger extract for shelf-life extention and quality retention of milkfish (chanos chanos). In AIP Conference Proceedings; AIP Publishing LLC: Melville, NY, USA, 2019; Volume 2085.

68. Rialita, T.; Nurhadi, B.; Puteri, R.D. Characteristics of microcapsule of red ginger (Zingiber officinale var. rubrum) essential oil produced from different arabic gum ratios on antimicrobial activity toward escherichia coli and staphylococcus aureus. Int. J. Food Prop. 2018, 21, 2500-2508. [CrossRef]

69. Handayani, H.; Achmad, H.; Suci, A.D.; Firman, M.; Mappangara, S.; Ramadhany, S.; Pratiwi, R.; Wulansari, D.P. Analysis of antibacterial effectiveness of red ginger extract (Zingiber Officinale Var Rubrum) compared to white ginger extract (Zingiber Officinale Var. Amarum) in mouth cavity bacterial streptococcus mutans (In-Vitro). J. Int. Dent. Med. Res. 2018, 11, 676-681.

70. Hanifah, A.; Tristantini, D. Total phenolic, UPLC-QTOF-MS analysis and antidepressant-like effect in the mice forced swim test of Jamu Neuropathic Pain Reducer. In AIP Conference Proceedings; AIP Publishing LLC: Melville, NY, USA, 2019 ; Volume 2193.

71. Chandra, D.; Korpi, E.R.; Miralles, C.P.; de Blas, A.L.; Homanics, G.E. GABAA receptor $\gamma 2$ subunit knockdown mice have enhanced anxiety-like behavior but unaltered hypnotic response to benzodiazepines. BMC Neurosci. 2005, 6, 1-13. [CrossRef]

72. Nogueira De Melo, G.A.; Grespan, R.; Fonseca, J.P.; Farinha, T.O.; Da Silva, E.L.; Romero, A.L.; Bersani-Amado, C.A.; Cuman, R.K.N. Inhibitory effects of ginger (Zingiber officinale Roscoe) essential oil on leukocyte migration in vivo and in vitro. J. Nat. Med. 2011, 65, 241-246. [CrossRef]

73. Vendruscolo, A.; Takaki, I.; Bersani-Amado, L.E.; Dantas, J.A.; Bersani-Amado, C.A.; Cuman, R.K.N. Antiinflammatory and antinociceptive activities of Zingiber officinale roscoe essential oil in experimental animal models. Indian J. Pharmacol. 2006, 38, 58. [CrossRef]

74. Safithri, M.; Kurniawati, A. Syaefudin Formula of Piper crocatum, Cinnamomum burmanii, and Zingiber officinale extracts as a functional beverage for diabetics. Int. Food Res. J. 2016, 23, 1123-1130.

75. Almasdy, D.; Martini, R.D.; Arman, E. The effect of dried red ginger powder Zingiber officinale var rubrum) on patients with type 2 diabetes. Ind. Complementary Ther. Nat. Disasters 2013, 13, 87-94.

76. Adefegha, S.A.; Oboh, G. Inhibition of key enzymes linked to type 2 diabetes and sodium nitroprusside-induced lipid peroxidation in rat pancreas by water extractable phytochemicals from some tropical spices. Pharm. Biol. 2012, 50, 857-865. [CrossRef] [PubMed] 
77. Koeberle, A.; Werz, O. Multi-target approach for natural products in inflammation. Drug Discov. Today 2014, 19, 1871-1882. [CrossRef] [PubMed]

78. Pan, M.H.; Lai, C.S.; Ho, C.T. Anti-inflammatory activity of natural dietary flavonoids. Food Funct. 2010, 1, 15-31. [CrossRef] [PubMed]

79. Sandrasari, D.A.; Sabariman, M.; Azni, I.N. Determination of potential level of Indonesian rhizomes as an antioxidant based on phenolic compound and antioxidant activity. In Proceedings of the IOP Conference Series: Earth and Environmental Science, Bogor, Indonesia, 10 May 2019; Volume 383.

80. Ippoushi, K.; Azuma, K.; Ito, H.; Horie, H.; Higashio, H. [6]-Gingerol inhibits nitric oxide synthesis in activated J774.1 mouse macrophages and prevents peroxynitrite-induced oxidation and nitration reactions. Life Sci. 2003, 73, 3427-3437. [CrossRef] [PubMed]

81. Peng, F.; Tao, Q.; Wu, X.; Dou, H.; Spencer, S.; Mang, C.; Xu, L.; Sun, L.; Zhao, Y.; Li, H.; et al. Cytotoxic, cytoprotective and antioxidant effects of isolated phenolic compounds from fresh ginger. Fitoterapia 2012, 83, 568-585. [CrossRef] [PubMed]

82. Surh, Y.J. Molecular mechanisms of chemopreventive effects of selected dietary and medicinal phenolic substances. In Mutation Research-Fundamental and Molecular Mechanisms of Mutagenesis; Elsevier: Amsterdam, The Netherlands, 1999; Volume 428, pp. 305-327.

83. Aeschbach, R.; Löliger, J.; Scott, B.C.; Murcia, A.; Butler, J.; Halliwell, B.; Aruoma, O.I. Antioxidant actions of thymol, carvacrol, 6-gingerol, zingerone and hydroxytyrosol. Food Chem. Toxicol. 1994, 32, 31-36. [CrossRef]

84. Iwasaki, Y.; Morita, A.; Iwasawa, T.; Kobata, K.; Sekiwa, Y.; Morimitsu, Y.; Kubota, K.; Watanabe, T. A nonpungent component of steamed ginger-[10]-shogaol-increases adrenaline secretion via the activation of TRPV1. Nutr. Neurosci. 2006, 9, 169-178. [CrossRef]

85. Wei, Q.-Y.; Ma, J.-P.; Cai, Y.-J.; Yang, L.; Liu, Z.-L. Cytotoxic and apoptotic activities of diarylheptanoids and gingerol-related compounds from the rhizome of Chinese ginger. J. Ethnopharmacol. 2005, 102, 177-184. [CrossRef]

86. Wang, G.; Li, X.; Huang, F.; Zhao, J.; Ding, H.; Cunningham, C.; Coad, J.E.; Flynn, D.C.; Reed, E.; Li, Q.Q. Antitumor effect of $\beta$-elemene in non-small-cell lung cancer cells is mediated via induction of cell cycle arrest and apoptotic cell death. Cell. Mol. Life Sci. 2005, 62, 881-893. [CrossRef]

87. Vimala, S.; Norhanom, A.W.; Yadav, M. Anti-tumour promoter activity in Malaysian ginger rhizobia used in traditional medicine. Br. J. Cancer 1999, 80, 110-116. [CrossRef]

88. Baliga, M.S.; Haniadka, R.; Pereira, M.M.; D'Souza, J.J.; Pallaty, P.L.; Bhat, H.P.; Popuri, S. Update on the chemopreventive effects of ginger and its phytochemicals. Crit. Rev. Food Sci. Nutr. 2011, 51, 499-523. [CrossRef]

89. Sung, B.; Jhurani, S.; Ahn, K.S.; Mastuo, Y.; Yi, T.; Guha, S.; Liu, M.; Aggarwal, B.B. Zerumbone down-regulates chemokine receptor CXCR4 expression leading to inhibition of CXCL12-induced invasion of breast and pancreatic tumor cells. Cancer Res. 2008, 68, 8938-8944. [CrossRef]

90. Ghasemzadeh, A.; Jaafar, H.Z.E.; Rahmat, A. Synthesis of phenolics and flavonoids in ginger (Zingiber officinale Roscoe) and their effects on photosynthesis rate. Int. J. Mol. Sci. 2010, 11, 4539-4555. [CrossRef]

91. Kostner, G.M.; Gavish, D.; Leopold, B.; Bolzano, K.; Weintraub, M.S.; Breslow, J.L. HMG CoA reductase inhibitors lower LDL cholesterol without reducing Lp(a) levels. Circulation 1989, 80, 1313-1319. [CrossRef] [PubMed]

92. Shim, S.; Kim, S.; Choi, D.S.; Kwon, Y.B.; Kwon, J. Anti-inflammatory effects of [6]-shogaol: Potential roles of HDAC inhibition and HSP70 induction. Food Chem. Toxicol. 2011, 49, 2734-2740. [CrossRef] [PubMed]

93. Afnan, N.T.; Nur, D.F.; Utami, T.S.; Sahlan, M.; Wijanarko, A.; Hermansyah, H. Producing armyworm (spodoptera sp.) bioinsecticide based on cysteine protease of red ginger (zingiber officinale var. Rubrum). In Proceedings of the IOP Conference Series: Materials Science and Engineering, Nanjing, China, 9-11 May 2018; Institute of Physics Publishing; Volume 316.

94. Supu, R.D.; Diantini, A.; Levita, J. Red ginger (Zingiber officinale var. rubrum): Its chemical constituents, pharmacological activities and safety. Fitofarmaka J. Ilm. Farm. 2019, 8, 23-29. [CrossRef]

95. Naveed, A.; Rehman, R.; Akram, M.; Akhtar, N.; Jabeen, Q.; Saeed, T.; Shah, S.M.A.; Ahmed, K.; Shaheen, G.; Asif, H.M. Zingiber officinale Roscoe (pharmacological activity). J. Med. Plants Res. 2011, 5, 344-348.

96. Al-Amin, Z.M.; Thomson, M.; Al-Qattan, K.K.; Peltonen-Shalaby, R.; Ali, M. Anti-diabetic and hypolipidaemic properties of ginger (Zingiber officinale) in streptozotocin-induced diabetic rats. Br. J. Nutr. 2006, 96, 660-666. [CrossRef]

97. ElMazoudy, R.H.; Attia, A.A. Ginger causes subfertility and abortifacient in mice by targeting both estrous cycle and blastocyst implantation without teratogenesis. Phytomedicine 2018, 50, 300-308. [CrossRef] 